\title{
Recent Patterns of Economic Alignment in the European (Monetary) Union
}

\author{
Agnieszka Gehringer ${ }^{1, *}$ and Jörg König ${ }^{2}$ \\ 1 Cologne University of Applied Sciences, 50868 Cologne, Germany \\ 2 Stiftung Marktwirtschaft, Europe, Energy, Competition, Growth and Development Policy, 10117 Berlin, \\ Germany; koenig@stiftung-marktwirtschaft.de \\ * Correspondence: agnieszka.gehringer@wiwi.uni-goettingen.de
}

Citation: Gehringer, Agnieszka, and Jörg König. 2021. Recent Patterns of Economic Alignment in the European (Monetary) Union. Journal of Risk and Financial Management 14: 362. https://doi.org/10.3390/jrfm14080362

Academic Editor: Shigeyuki Hamori

Received: 8 July 2021

Accepted: 3 August 2021

Published: 6 August 2021

Publisher's Note: MDPI stays neutral with regard to jurisdictional claims in published maps and institutional affiliations.

Copyright: (c) 2021 by the authors. Licensee MDPI, Basel, Switzerland. This article is an open access article distributed under the terms and conditions of the Creative Commons Attribution (CC BY) license (https:/ / creativecommons.org/licenses/by/ $4.0 /)$.

\begin{abstract}
This paper studies the process of business cycle synchronization in the European Union and the euro area. As our baseline methodology we adopt rolling window correlation coefficients of various economic indicators, observed since 2000. Among the indicators, we distinguish between real economic indicators, like the real GDP growth and unemployment, and nominal indicators, like inflation and government budget. Given the direct implication of this kind of analysis for the common monetary policy of the European Central Bank (ECB), special attention is paid to the pattern of business cycle synchronization in the core and peripheral members of the euro area. Our analysis of quarterly data covering the first two decades of the euro area shows that there was a certain synchronization tendency in the first years of the common currency. However, the European debt crisis halted the economic integration within the European Union and-even more so-within the euro area. Since the ECB can to a large extent intervene only with "one-size-fits-all" monetary policy instruments, this renders increasingly cumbersome the conduct of stabilisation policies within the euro area.
\end{abstract}

Keywords: European Union; euro; economic integration; business cycle synchronization; disintegration

\section{Introduction}

During the entire process of European integration in the post-war era, the desire to take economic advantage from a common, integrated market was constantly pursued. On its establishment in 1957, one of the core objectives of the European Economic Community (EEC) was the development of a common market offering free movement of goods, services, capital and people. This approach to integration was further emphasized with the establishment of the European Single Market and the European Union (EU) in 1993 and subsequently with the introduction of the Euro in 1999.

An important ingredient and at the same time precondition for economic gains stemming from this process of European integration is a sufficient degree of economic synchronization within the integrating area (Cecchini et al. 1988; Müller and Buscher 1999; Notaro 2011; Nikolov 2016). This is even more important when the step of monetary integration is taken (Mundell 1961; McKinnon 1963; Kenen 1969; Eichengreen 1991; Gächter et al. 2012).

In this paper, we take a closer look at the process of business cycle synchronization within the EU and the euro area. Our aim is to assess how this process evolved over the past two decades and thus whether it eventually contributed to sustain and strengthen European integration. The contribution of our paper is twofold in this regard. First, we look in a detailed manner over space, time and indicators at the EU as a whole and its different subsamples, with a special focus put on the euro area. Moreover, since the noneuro members of the EU are formally obliged to once join the euro area, we also carefully analyse the degree of economic alignment of this specific country group. In this way, we extend our understanding regarding the various dynamics of economic activity within the $\mathrm{EU}$ and the influence thereof on the ECB's policy making under current and potentially 
enlarged euro area. Second, we adopt a broad view on business cycle synchronization, which encompasses other economic variables than only gross domestic product. More precisely, we include such indicators as industrial production, unemployment, youth unemployment, labour productivity, government budget balance, headline inflation, core inflation and long-term interest rates. The motivation behind is to gather a broader view at cyclical developments of European economies and their underlying economic alignment.

In doing so, we follow in spirit the methodology used by König and Ohr (2013) to construct the measure of EU-symmetry within their broader EU-Index. Consistently with König and Ohr (2013), we apply the rolling correlation coefficients as our baseline statistical framework. At the same time, we slightly modify their original setting by extending the set of economic indicators under investigation. Moreover, we extend the time coverage up to 2019. Thereby, we get additional insights on the more recent developments of business cycle alignment of the member states. Finally, rather than building a comprehensive measure of EU-symmetry, we look at each single economic indicator, with the aim to get amore in depth understanding of the underlying economic forces.

Furthermore, the relevance of our approach to analyse business cycle co-movements derives from the fact that it shows an important aspect of the advancement in the broader process of economic integration. This, in turn, is important both to legitimize further integration efforts in the $\mathrm{EU}$ as a whole and to better understand the economic policy framework of the ECB, which is conditioned on a sufficient degree of economic alignment in the monetary union. Regarding the EU, our analysis should be supportive to further monitor and assess economic integration efforts, for instance, as pursued by the European Commission, which regularly analyses budgetary plans and macroeconomic challenges of the EU member states in the so-called European Semester.

Our results show that the degree of economic alignment between the member states initially improved in some areas but stagnated at best in the period after the European sovereign debt crisis. This is especially true for the euro area members and within them for the peripheral countries (Greece, Ireland, Italy, Portugal, and Spain). Consequently, the lack of economic commonalities within the euro area might have made it increasingly difficult to conduct common monetary policy. In turn, this might help explaining why the European integration project and especially the Economic and Monetary Union (EMU) does not seem to fulfil the initial economic expectations of many member states (Diaz del Hoyo et al. 2017; Duarte and Gehringer 2020). Accordingly, EMU is far from being the promised "stability union". At the same time, also the prospects for an enlarged monetary union are blurred, given the low degree of economic alignment of the prospective euro members.

In what follows, this paper shows a data-based evidence of the evolution of the cyclical alignment within the $\mathrm{E}(\mathrm{M}) \mathrm{U}$. The next section offers a brief literature review setting the conceptual context of our analysis. Section 3 describes our methodology and data. In Section 4, we show the results of our main computations, whereas in Section 5 we perform complementary analysis with an alternative method Section 6 is dedicated to discuss the economic policy options to render the union more complete and to delineate the underlying drawbacks. The last section concludes.

\section{Literature Review}

The post-1945 European integration process was propelled by a broad mix of economic and non-economic impulses. Indeed, European integration has always included objectives going beyond the pure economic sphere (Bulmer 2007). However, with the publication of the White Paper on Completing the Internal Market from 1985 and the subsequent establishment of the EU on 1 November 1993, the aim to create an integrated economic community where national borders neither impede trade nor the movement of production factors was strongly emphasized (European Commission 1985). This was based on the conviction that a functioning and integrated European market may contribute to economic growth and prosperity by stimulating competition and industrial readjustment, improving 
efficiency, raising quality, lowering costs and in turn prices, and contributing to a stream of innovations (Cecchini et al. 1988; Notaro 2011). Integrated markets can also enhance the shock absorption capacity of the union, i.e., through better access to international capital and credit markets (European Commission 1990; Müller and Buscher 1999; Gehringer 2013; Nikolov 2016).

Moreover, economic integration-particularly in terms of business cycle synchronizat ion-is a vital precondition for a smooth functioning of a union with fixed exchange rates and common monetary policy, as is the case of the euro area. The crucial role of business cycle synchronization for a prosperous currency area is one of the main postulates of the standard theory of the Optimum Currency Area (OCA), developed by Mundell (1961), McKinnon (1963) and Kenen (1969). A currency area is optimal, if a sufficient degree of real economic integration between regions-in terms of aligned developments in goods, services and factor markets-is achieved. Well integrated factor markets, supported by flexible prices and wages as well as diversified product and investment portfolios, may serve in turn as an efficient adjustment mechanism to mitigate the negative effects of asymmetric shocks. ${ }^{1}$ Under optimality conditions of the currency area, and thus sufficiently aligned business cycles of its members, the central bank can more easily conduct stabilization policies (Rogoff 1985; Clarida et al. 1999; Belke et al. 2017). Moreover, synchronized business cycles between the members are deemed in turn to reduce the risk of asymmetric shocks occurring within the area (Altavilla 2004). If optimality of the currency area is not given, the loss of economic stability weighs more than the gain in monetary efficiency from participating in the fixed exchange rate system (Babetskii 2005; Krugman et al. 2018).

The relevance of the business cycle synchronization as a catalyst and pre-condition of the ongoing integration in Europe is reflected in an impressive body of the literature dealing with this issue. There is a well-established literature analysing the business cycle synchronization within the euro area. Focusing on the preparation stage to the euro introduction, Eichengreen (1991) as well as Dickerson et al. (1998) report low correlation of economic shocks among candidate countries. In contrast to this finding, De Grauwe and Ji (2016) find a high degree of business cycle alignment among euro area members over the period 1995-2014. The question, whether this is a confirmation of an endogenous process of increasing synchronization due to the common currency is, nevertheless, open. There are studies tending to confirm this hypothesis (Altavilla 2004; Gächter and Riedl 2014; Oman 2019). Other contributions, however, find limited evidence that this would be eventually the case (McCarthy and Sørensen 2006; Papageorgiou et al. 2010; Lehwald 2013; Miles and Vijverberg 2018). In particular, Degiannakis et al. (2014) and Camacho et al. (2020) find evidence of a declining degree of business cycle synchronization across the euro area in the aftermath of the financial and the European sovereign debt crisis. ${ }^{2}$

These diverging results are broadly reflected in the conceptual dispute concerning the effect of setting a unified monetary framework, with a common currency and a supranational monetary policy making. There are two diverging explanations. The first view sees the intensifying trade and financial market relations within the monetary union among the main catalysts of increasing business cycle synchronisation (Engel and Rogers 1996; Frankel and Rose 1997, 1998; Rose 2000; Rose and Stanley 2005). To the contrary, the second view argues that the synchronisation of the business cycles within the currency area would diminish mainly due to increasing industrial specialization and spatial concentration of economic activity (Krugman 1979, 1991a, 1991b). Additionally, De Haan et al. (2002) assert that monetary integration could lower business cycle synchronization due to the renouncement of the stabilization through the exchange rate channel.

Another relevant strand of the literature dedicated to the investigation of the business cycle synchronization within the euro area points to an intensifying division between core and peripheral countries. Lehwald (2013) finds that the euro negatively impacted the synchronization by peripheral countries - among which are Spain, Portugal, Greece, and Ireland-but enhanced co-movements within the core of the euro area. Along these lines, the studies by Guerini et al. (2019), Belke et al. (2017), Konstantakopoulou and Tsionas 
(2011), and Gouveia and Correia (2008) confirms a stronger synchronization within the core euro area and diminishing alignment in the periphery (especially Greece and Portugal).

At the same time, the analysis of the degree of synchronization and of the underlying trends thereof in the EU as a whole has received much less attention so far. This might be justified on the grounds that business cycle synchronization is customarily perceived as a precondition for the functioning of a monetary union, with less relevance in a union, in which member countries still enjoy sovereignty in monetary matters. However, since the EU members currently not participating in the euro area are formally obliged to once join the monetary union, it is important to track the degree of their alignment with the future enlarged euro area. Accordingly, the results by Antonakakis and Tondl (2014) suggest that trade and foreign direct investments enhanced business cycle synchronization between incumbent and new EU members and that rising specialization has not have any detrimental effect on the degree of business cycle co-movements across the EU. They also find evidence that the lack of fiscal discipline in the EU is a driving force of economic misalignment across the union. In a comparative setting, distinguishing between euro and non-euro area members, Campos et al. (2019) confirm a quite substantial increase of synchronization for both country groups. At the same time, increased synchronization seems to have occurred unevenly across countries and economic variables. Whereas some new EU members-especially Hungary, Poland, and Slovenia-were able to achieve a higher degree of economic alignment, particularly in terms of GDP, others lagged behind or experienced no synchronization (Darvas and Szapáry 2008). However, there is also some evidence that small EU countries performed better in terms of synchronization (Filipovski et al. 2018).

More recently and accounting for conflicting results from the previous empirical literature, Beck (2019) considers a comprehensive set of various factors potentially determining business cycle synchronization and-based on the method of Bayesian model averaging together with jointness measures-finds strong evidence for an interplay of eight economic factors, among which intra-industry trade and capital mobility driving business cycle co-movements in the EU.

It is important to note that from the conceptual point of view, business cycle synchronization was not always embedded within the analysis of the process of economic integration. The concept of economic integration dates back to the seminal works by Jacob Viner in the early 1950s, discussing the possible static benefits of integration in terms of intensifying trade relations between economies (Viner 1950). Subsequently, starting in the 1960s, Bela Balassa broadened this line of analysis of the process of economic integration by introducing the instrument of dynamic effects (Balassa 1961).

Whereas the early theories of economic integration focused on the analysis of the stages and the determinants of economic integration, later contributions turned to emphasise the impact of the integration process on economic performance (e.g., Badinger 2005; Baldwin 2006). However, a careful screening of the dedicated literature suggests that economic integration was often used in this context interchangeably with economic convergence (e.g., Nikolov 2016), with only limited attention dedicated to business cycle synchronization. Instead, a more granular view suggests that economic integration may encompass both economic convergence and business cycle synchronization (König and Ohr 2013). ${ }^{3}$

\section{Methodology and Data}

Our measurement of the degree of business cycle synchronization is related to the "EU symmetry" dimension of broader EU integration, as measured in the EU-Index by König and Ohr (2013). ${ }^{4}$ The latter is based on the most common indicators used to capture the co-movement of business cycles, namely the seasonal, calendar and trend adjusted time series of $\mathrm{GDP}^{5}$ growth rate, inflation rate, change in employment, and the balance of government budget as a percentage of GDP. In this paper, we extend the list of analysed indicators to arrive at a more granular view of the underlying integration process. 
In particular, to better assess the degree of nominal integration, we look not only at the headline but also at the core inflation rate (i.e., excluding volatile components of energy and food prices). The inclusion of the core inflation is insofar justified that the ECB's monetary policy making is oriented to the monitoring of medium-term inflation dynamics, thus looking beyond the short-term price fluctuations, driven particularly by energy and food prices. Consequently, the co-movement of inflation cycles should be lower when prices which are largely driven by common global factors are omitted. Additionally, we include the 10-year government bond yield. Based on this indicator, we are able to track the degree of financial market alignment, given that all market interest rates on money, bond and credit markets are typically dependent on and derive from the risk-free rates on government bonds.

For the analysis of real integration, we include not only the overall unemployment rate, but also youth unemployment, given the divergent experiences within the EU especially in this segment of the labour markets. Additionally, we include labour productivity and industrial production growth rate in order to get a broader view on economic activity, going beyond gross domestic product. ${ }^{6}$ Although labour productivity is customarily analysed in the context of long-run growth, its constituent elements, output and labour input, behave strongly cyclically, which should justify its inclusion in our framework. In this way, we extend our analysis of the business cycle by efficiency considerations.

Following the approach of König and Ohr (2013), we calculate pairwise Pearson correlations between the country's value of each indicator and its population weighted average value of the remaining members of the relevant country aggregate, according to the following formula:

$$
r=\frac{\sum\left(x_{i t}-\bar{x}\right)\left(y_{i t}-\bar{y}\right)}{\sqrt{\sum\left(x_{i t}-\bar{x}\right)^{2}} \sum\left(y_{i t}-\bar{y}\right)^{2}}
$$

where $x_{i t}$ is the value of indicator (e.g., growth rate of real GDP) in country $i$ at time $t, \bar{x}$ its average over a period of 20 quarters preceding $t$, and $y_{i t}$ as well as $\bar{y}$ are the respective values of the relevant country aggregate.

Regarding the latter, we use two aggregates, the EU and the euro area. The pairwise correlations are reported on a yearly basis as a moving average over a period of 20 quarters. The correlation coefficient can assume values between 1 (maximum integration) and -1 (maximum disintegration). The current data availability ranges between 1999Q1 and 2019 Q4.

The above method is our baseline strategy, given that in our calculations we aim to remain as close as possible to the methodology adopted in König and Ohr (2013). However, we complement our analysis by a second method based on the so called instantaneous quasi-correlations, as proposed by Abiad et al. (2013) and discussed in Section 5 below. It ought to be noted that this procedure should not be interpreted as alternative, but rather complementary to our baseline, given that from the methodological point of view they are based on substantially different framework, which makes the direct comparability of results cumbersome.

Our sample includes the EU28 members with the exception of Luxembourg, since the country displays many extreme values in several indicators included in our analysis. At the same time, we include the UK, which until recently has participated in the EU.

\section{Results}

In the tables below, we show averages of country-level correlation coefficients calculated for important country groups, namely, EU, Euro, Euro core, Euro periphery and EU Non-Euro. Where suitable we comment on remarkable single country developments. ${ }^{7}$

In interpreting the numbers, beyond looking at the absolute values of the correlation coefficients, it is also important to focus on the underlying tendency of the coefficients over time. Regarding the levels, the comparison of the coefficients between country groups or single countries is insightful to detect differences in the advancement of business cycle 
synchronization. In general terms, a country is integrated with the rest of the union for sufficiently high values of correlation coefficients. For low or negative coefficients, disintegration is the case. The analysis of the tendency of coefficients over time is useful in tracking the direction of the process. We speak about an ongoing integration process, provided that the correlation coefficients tend to increase, as this implies that the underlying developments between the country and the corresponding EU or euro area average are becoming more symmetric. The more symmetric the cyclical co-movements, the more suitable the common monetary policy for the union in general and for single member states actively involved in the integration process. To the contrary, disintegration takes place if correlation coefficients are very low (or even negative) or if they fall over time.

One important observation is still due here. The values of the indicators around the crisis years should be interpreted with caution. This is because economic crises-especially these having a global dimension, like the one triggered by the Great Financial Crisis in 2008-often lead to a one-off and area-wide negative cyclical reaction. Consequently, rising correlation coefficients during economic crisis might give a false sense of intensifying economic integration. Therefore, we do not analyse longer periods as a block, in contrast to, for instance, Franks et al. (2018). For this reason, in interpreting the numbers, we tend to concentrate on periods of normal economic activity over cyclical developments. Moreover, we analyse instantaneous quasi-correlations in a separate section to correct for autocorrelations in the wake of crisis years.

\subsection{Real Integration}

In terms of real GDP growth rates (Table 1 ), the EU as a whole became more symmetric in the years before the 2008 crisis, but only on fairly low levels, reaching 0.35 just before the outbreak of the crisis. Following the peak of the subsequent European sovereign debt crisis between 2010 and 2012, the process has reversed or at least has not deepened compared with the pre-crisis levels. These dynamics at fairly low levels were widespread, with real disintegration taking place recently both in Euro core and-even more-in Euro periphery. Also, EU non-euro members displayed low and declining levels of symmetry after the crisis years, yet with a slight upward tendency in the most recent years.

At the single-country level, the most remarkable developments occurred in Germany and Ireland. In the case of Germany, its above-average alignment with the euro area average in the period before the European sovereign debt crisis reversed thereafter and turned into a process of disintegration, with even negative correlation coefficients in Germany in the most recent years. Similar experience regards Ireland, with the difference that the country has never reached an appreciable level of economic integration with the rest of euro area. In the most recent years, the country showed increasing fatigue in reverting this tendency (Figure 1).

A similar disintegration tendency is visible in the field of industrial production growth (Table 2), with the levels of alignment both across the EU and the euro area showing a similar pattern observed for real GDP growth. Again, the correlation coefficients only reach higher levels when crisis periods are included in the assessment. This disintegration tendency becomes especially apparent in the core group of euro area member states. In fact, the downward trend was already in place before the Great Financial Crisis and turned to even more negative values after the euro area debt crisis. From 2014 to 2018 almost all euro area member states ran through a period of rising economic growth rates, yet without being able to synchronize their business cycles. These findings have an important interpretation for the euro area as it seems to provide evidence against the endogeneity hypothesis of the OCA, according to which the progressive alignment of the internal market and of productive structures would allow the monetary union to generate internal-endogenousforces, making it increasingly integrated ex post. Despite some-although not particularly high-degree of economic integration in the first years of the euro area and the very last year, the process weakened gradually in the years following the European sovereign debt crisis. 
Table 1. Real GDP growth rates-averages of country-level correlation coefficients for different country groups.

\begin{tabular}{cccccc}
\hline & EU & Euro & Euro Core & Euro Periphery & EU Non-Euro \\
\hline $2000-2004$ & 0.20 & 0.23 & 0.38 & 0.30 & 0.14 \\
$2001-2005$ & 0.22 & 0.22 & 0.32 & 0.28 & 0.16 \\
$2002-2006$ & 0.34 & 0.41 & 0.47 & 0.47 & 0.28 \\
$2003-2007$ & 0.35 & 0.39 & 0.47 & 0.43 & 0.28 \\
$2004-2008$ & 0.60 & 0.59 & 0.74 & 0.60 & 0.56 \\
$2005-2009$ & 0.72 & 0.74 & 0.86 & 0.68 & 0.66 \\
$2006-2010$ & 0.71 & 0.73 & 0.86 & 0.65 & 0.65 \\
$2007-2011$ & 0.70 & 0.71 & 0.87 & 0.61 & 0.64 \\
$2008-2012$ & 0.68 & 0.70 & 0.87 & 0.60 & 0.64 \\
$2009-2013$ & 0.68 & 0.70 & 0.89 & 0.57 & 0.60 \\
$2010-2014$ & 0.45 & 0.49 & 0.70 & 0.39 & 0.39 \\
$2011-2015$ & 0.36 & 0.35 & 0.49 & 0.33 & 0.34 \\
$2012-2016$ & 0.33 & 0.33 & 0.41 & 0.39 & 0.33 \\
$2013-2017$ & 0.24 & 0.29 & 0.38 & 0.19 & 0.13 \\
$2014-2018$ & 0.23 & 0.24 & 0.26 & 0.14 & 0.19 \\
$2015-2019$ & 0.26 & 0.25 & 0.28 & 0.17 & 0.29 \\
\hline
\end{tabular}

Source: Own calculations, based on Macrobond. Note: In what follows, EU refers to 27 EU members (EU-28 excluding Luxembourg), Euro includes 18 Euro countries, Euro core is the average across Austria, Belgium, Finland, France, Germany and the Netherlands and Euro periphery is the average across Greece, Ireland, Italy, Portugal and Spain. EU Non-Euro refers to EU member countries currently not participating in the euro-area, but formally obliged to once join the monetary union, namely, Bulgaria, Croatia, Czech Republic, Denmark, Hungary, Poland, Romania, and Sweden. In calculating the average correlation coefficients for the country groups of EU and EU Non-Euro, the relevant country aggregate when computing the single-country correlation coefficients is the EU, whereas for Euro, Euro core and Euro periphery it is the euro area.

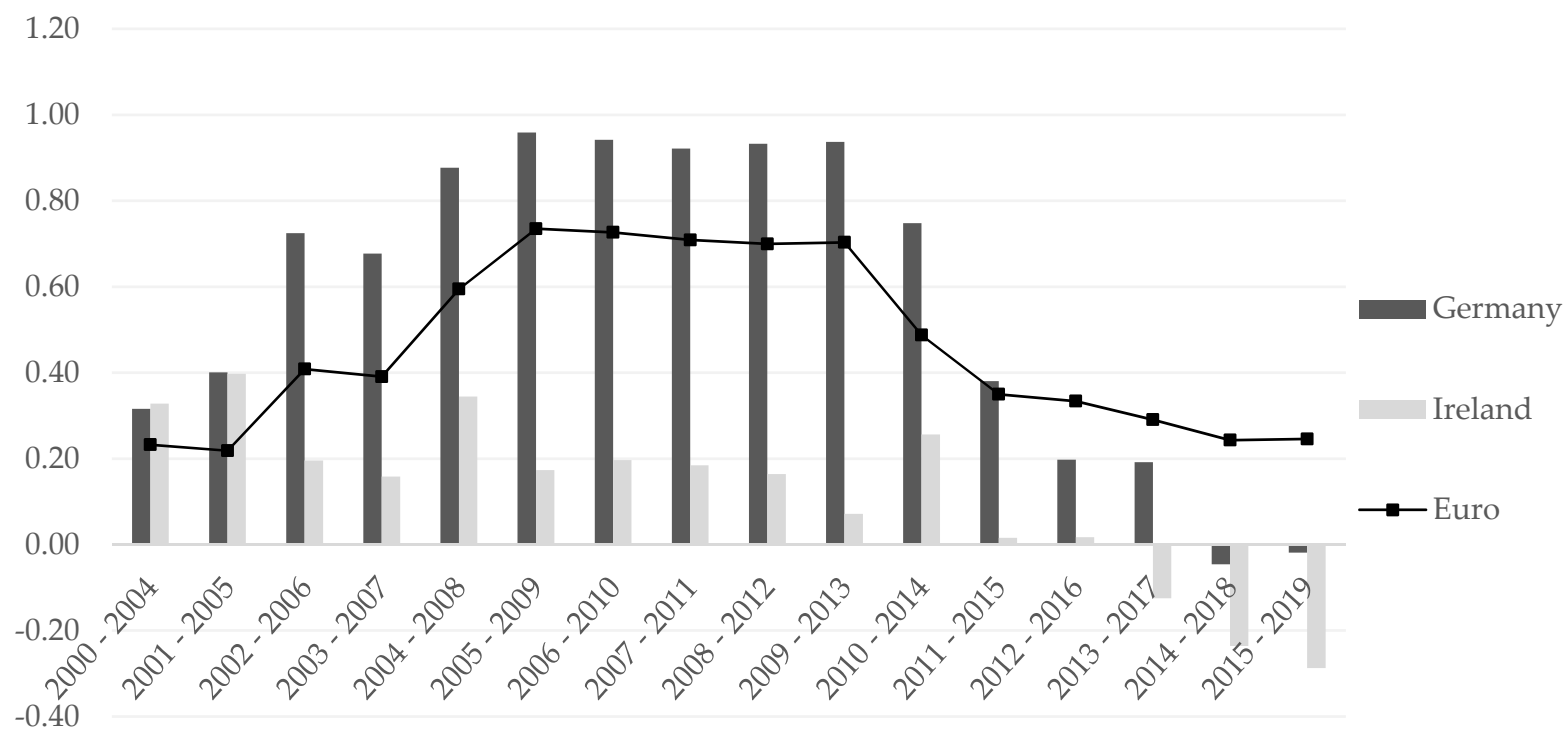

Figure 1. Correlation coefficients for real GDP growth rates. Source: Own calculations, based on Macrobond. 
Table 2. Industrial production growth rates-averages of country-level correlation coefficients for different country groups.

\begin{tabular}{cccccc}
\hline & EU & Euro & Euro Core & Euro Periphery & EU Non-Euro \\
\hline $2000-2004$ & 0.24 & 0.26 & 0.38 & 0.19 & 0.08 \\
$2001-2005$ & 0.19 & 0.25 & 0.30 & 0.30 & -0.02 \\
$2002-2006$ & 0.17 & 0.25 & 0.18 & 0.47 & -0.02 \\
$2003-2007$ & 0.19 & 0.25 & 0.08 & 0.43 & 0.07 \\
$2004-2008$ & 0.58 & 0.56 & 0.57 & 0.57 & 0.58 \\
$2005-2009$ & 0.55 & 0.52 & 0.56 & 0.48 & 0.56 \\
$2006-2010$ & 0.60 & 0.56 & 0.62 & 0.52 & 0.61 \\
$2007-2011$ & 0.61 & 0.57 & 0.67 & 0.50 & 0.65 \\
$2008-2012$ & 0.60 & 0.56 & 0.68 & 0.48 & 0.64 \\
$2009-2013$ & 0.39 & 0.39 & 0.43 & 0.38 & 0.38 \\
$2010-2014$ & 0.38 & 0.39 & 0.33 & 0.49 & 0.35 \\
$2011-2015$ & 0.28 & 0.35 & 0.20 & 0.53 & 0.16 \\
$2012-2016$ & 0.22 & 0.31 & 0.14 & 0.45 & 0.02 \\
$2013-2017$ & 0.18 & 0.24 & 0.00 & 0.36 & 0.02 \\
$2014-2018$ & 0.17 & 0.21 & -0.05 & 0.32 & 0.04 \\
$2015-2019$ & 0.28 & 0.29 & 0.11 & 0.40 & 0.19 \\
\hline
\end{tabular}

Source: Own calculations, based on Macrobond.

Finally, it is remarkable to note that EU non-euro members are the least aligned with the EU and thus with the potentially enlarged euro area. This does not offer any encouraging prospect for the common monetary policy of an enlarged euro area.

The developments described so far are partly reflected in the stagnating or even progressively weakening integration of labour productivity growth, despite overall higher degree of alignment than in the case of the preceding two indicators (Table 3). However, here the tendency is especially visible in the group of the euro periphery. The higher euro core coefficients seem to level-out the lower euro periphery coefficients. These results thus show that there is some albeit declining synchronisation in terms of economic efficiency.

Table 3. Labour productivity growth rates-averages of country-level correlation coefficients for different country groups-labour productivity growth rates.

\begin{tabular}{cccccc}
\hline & EU Average & Euro & Euro Core & Euro Periphery & EU Non-Euro \\
\hline $2000-2004$ & 0.63 & 0.69 & 0.83 & 0.74 & 0.56 \\
$2001-2005$ & 0.65 & 0.71 & 0.84 & 0.74 & 0.57 \\
$2002-2006$ & 0.66 & 0.73 & 0.84 & 0.76 & 0.57 \\
$2003-2007$ & 0.65 & 0.72 & 0.85 & 0.74 & 0.59 \\
$2004-2008$ & 0.64 & 0.70 & 0.85 & 0.70 & 0.61 \\
$2005-2009$ & 0.69 & 0.72 & 0.86 & 0.67 & 0.73 \\
$2006-2010$ & 0.68 & 0.69 & 0.85 & 0.61 & 0.74 \\
$2007-2011$ & 0.67 & 0.68 & 0.83 & 0.56 & 0.73 \\
$2008-2012$ & 0.67 & 0.66 & 0.80 & 0.51 & 0.73 \\
$2009-2013$ & 0.69 & 0.67 & 0.80 & 0.54 & 0.73 \\
$2010-2014$ & 0.66 & 0.63 & 0.75 & 0.53 & 0.68 \\
$2011-2015$ & 0.66 & 0.62 & 0.73 & 0.52 & 0.69 \\
$2012-2016$ & 0.68 & 0.64 & 0.76 & 0.55 & 0.69 \\
$2013-2017$ & 0.68 & 0.63 & 0.76 & 0.53 & 0.68 \\
$2014-2018$ & 0.67 & 0.61 & 0.76 & 0.49 & 0.69 \\
$2015-2019$ & 0.65 & 0.60 & 0.73 & 0.47 & 0.64 \\
\hline
\end{tabular}

Source: Own calculations, Flossbach von Storch Research Institute, based on Macrobond.

However, a closer look at the single-country developments reveals some non-negligible heterogeneity. Germany and Ireland are again outliers here. Both countries displaced high symmetry with euro area in the years preceding the Great Financial Crisis, with correlation coefficients in Ireland among the highest in euro area (reaching 0.83 in 2005) and above the euro-area-average in Ireland. However, this high degree of economic alignment has 
declined since to a low of 0.11 for Germany in 2019. Correlation coefficients in Ireland turned negative in the wake of the European debt crisis (Figure 2). At the same time, it is important to note that behind the declining alignment in the two countries are diverging productivity performances, with Ireland experiencing above-average productivity growth, whereas Germany rather lagging behind the euro area average (Figure 3).

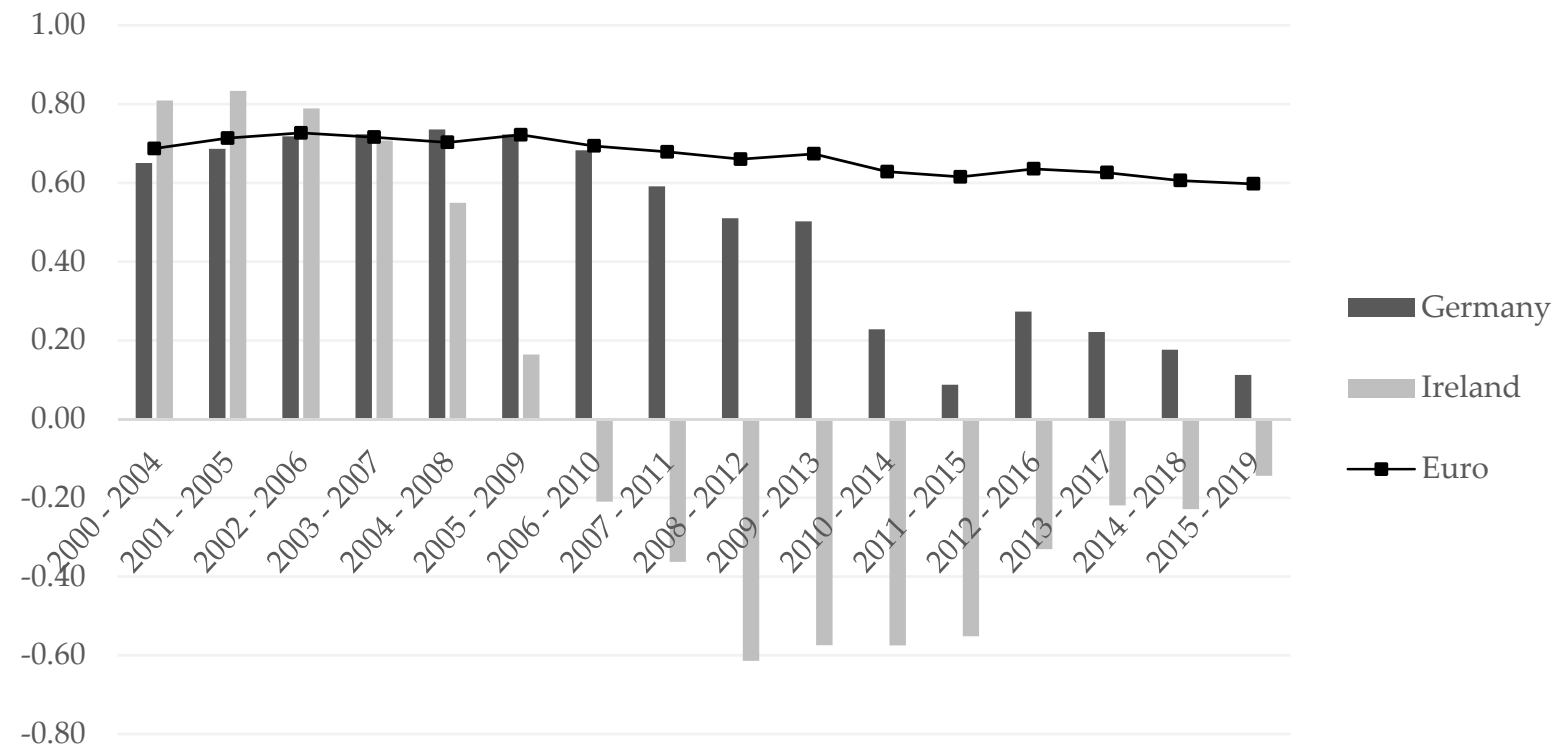

Figure 2. Correlation coefficients for productivity growth. Source: Own calculations, based on Macrobond.

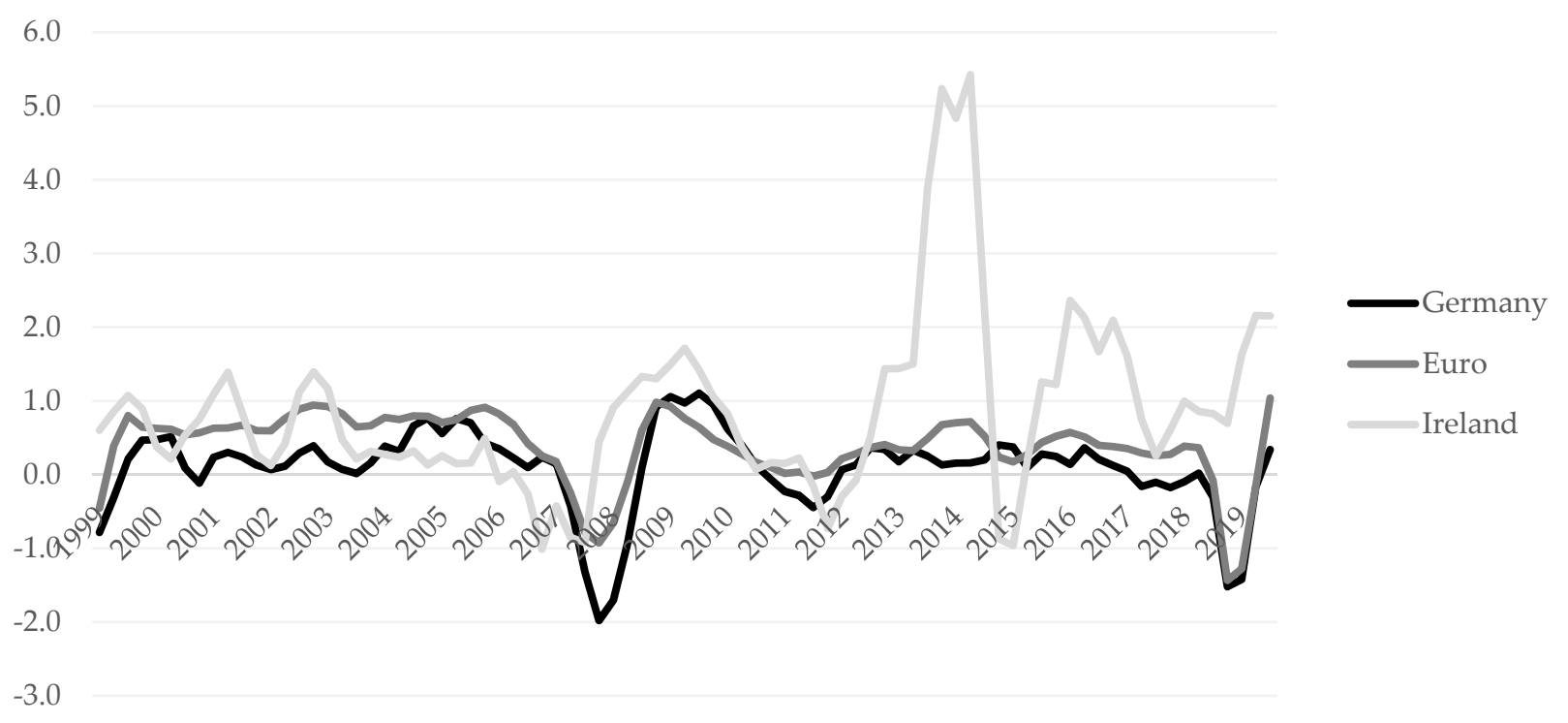

Figure 3. Labour productivity growth in euro area, Germany and Southern euro area members. Source: Own calculations, based on Macrobond. Note: Quarterly growth rates are reported as rolling moving averages over a one-year period. Southern Euro includes Greece, Italy, Portugal and Spain.

Weakening to almost non-existing economic alignment has also taken place in the labour markets (Tables 4 and 5). The low levels of correlation coefficients show that the labour markets were barely integrated already at the start of the euro, although a slight improvement could be observed thereafter. However, disintegration tendencies, especially within the peripheral euro area members, took over in the years following the European debt crisis. Behind the diverging growth fortunes, there was a weak economic performance of especially Southern euro area members relative to the rest of the euro area. This in turn 
could have contributed to the deterioration in structural and technological characteristics in the South, which eventually led to a substantial increase in unemployment rates in the wake of the Great Financial Crisis and later in the events of the European sovereign debt crisis (Bolea et al. 2018). An explanation for the missing symmetry in the labour market developments points to the fact that labour market (and social) policies are ever since in the hands of national governments. The different institutional settings, rigidities and preferences across the member states are likely reflected in low symmetry of their labour market developments.

Table 4. Unemployment rate growth-averages of country-level correlation coefficients for different country groups.

\begin{tabular}{cccccc}
\hline & EU & Euro & Euro Core & Euro Periphery & EU Non-Euro \\
\hline $2000-2004$ & 0.06 & 0.12 & 0.04 & 0.29 & -0.06 \\
$2001-2005$ & 0.03 & 0.11 & 0.02 & 0.28 & -0.11 \\
$2002-2006$ & 0.22 & 0.25 & 0.19 & 0.24 & 0.22 \\
$2003-2007$ & 0.33 & 0.31 & 0.15 & 0.31 & 0.38 \\
$2004-2008$ & 0.32 & 0.24 & 0.13 & 0.27 & 0.40 \\
$2005-2009$ & 0.60 & 0.56 & 0.56 & 0.55 & 0.64 \\
$2006-2010$ & 0.63 & 0.59 & 0.57 & 0.59 & 0.66 \\
$2007-2011$ & 0.61 & 0.56 & 0.53 & 0.57 & 0.66 \\
$2008-2012$ & 0.58 & 0.53 & 0.52 & 0.56 & 0.63 \\
$2009-2013$ & 0.63 & 0.62 & 0.65 & 0.62 & 0.61 \\
$2010-2014$ & 0.30 & 0.33 & 0.37 & 0.39 & 0.17 \\
$2011-2015$ & 0.24 & 0.27 & 0.32 & 0.34 & 0.09 \\
$2012-2016$ & 0.15 & 0.19 & 0.21 & 0.35 & 0.09 \\
$2013-2017$ & 0.12 & 0.15 & 0.02 & 0.39 & 0.01 \\
$2014-2018$ & 0.08 & 0.11 & -0.06 & 0.27 & \\
$2015-2019$ & 0.15 & 0.09 & -0.02 & 0.20 & \\
\hline
\end{tabular}

Source: Own calculations, Flossbach von Storch Research Institute, based on Macrobond.

Table 5. Youth unemployment rate growth-averages of country-level correlation coefficients for different country groups.

\begin{tabular}{cccccc}
\hline & EU & Euro & Euro Core & Euro Periphery & EU Non-Euro \\
\hline $2000-2004$ & 0.10 & 0.16 & 0.34 & 0.09 & -0.03 \\
$2001-2005$ & 0.04 & 0.12 & 0.28 & 0.01 & -0.05 \\
$2002-2006$ & 0.22 & 0.25 & 0.34 & 0.15 & 0.22 \\
$2003-2007$ & 0.31 & 0.28 & 0.36 & 0.15 & 0.37 \\
$2004-2008$ & 0.32 & 0.31 & 0.34 & 0.23 & 0.31 \\
$2005-2009$ & 0.51 & 0.49 & 0.53 & 0.45 & 0.51 \\
$2006-2010$ & 0.51 & 0.51 & 0.56 & 0.45 & 0.48 \\
$2007-2011$ & 0.49 & 0.48 & 0.51 & 0.43 & 0.47 \\
$2008-2012$ & 0.43 & 0.43 & 0.47 & 0.37 & 0.39 \\
$2009-2013$ & 0.47 & 0.45 & 0.47 & 0.45 & 0.48 \\
$2010-2014$ & 0.17 & 0.20 & 0.23 & 0.26 & 0.11 \\
$2011-2015$ & 0.11 & 0.09 & 0.08 & 0.21 & 0.14 \\
$2012-2016$ & 0.06 & 0.04 & 0.02 & 0.14 & 0.10 \\
$2013-2017$ & 0.04 & 0.06 & 0.04 & 0.04 & -0.04 \\
$2014-2018$ & 0.03 & 0.07 & 0.06 & -0.01 & -0.09 \\
$2015-2019$ & 0.01 & 0.05 & 0.08 & -0.13 & \\
\hline
\end{tabular}

Source: Own calculations, based on Macrobond.

The labour-market disconnect between EU members is visible with particular severity in youth unemployment rate dynamics (Table 5). Correlation coefficients were always very low-again, especially in the Euro periphery. However, the correlation coefficients declined remarkably after the 2008 crisis and are extremely low or even negative. Similarly discouraging is the picture in non-euro EU members, where increasing asymmetry dominated the stage in the most recent years. 
The sovereign debt crisis eventually led to diverging developments in government finances within both the European Union and euro area, with permanently high deficits in the Southern members and mostly improving government balances in the North. ${ }^{8}$ This divergence is reflected in diminishing correlation coefficients for the government budget balances during the sovereign debt crisis (Table 6). Only the last two observations offer a brighter picture, with slightly increasing correlation coefficients across the different country groups. There are at least two explanations for this. First, convenient cyclical conditions over the recent years permitted-especially countries with tendentially weak public finances-to improve their cyclical budget stances and thus align it to the respective $\mathrm{EU}$ or euro area average. Second, the low-interest-rate environment and, connected with this, monetary policies of the ECB and other national banks of the non-euro members offer convenient refinancing conditions for the national governments across the EU.

Table 6. Government budget balance as a percentage of GDP_averages of country-level correlation coefficients for different country groups.

\begin{tabular}{cccccc}
\hline & EU & Euro & Euro Core & Euro Periphery & EU Non-Euro \\
\hline $2000-2004$ & 0.26 & 0.12 & 0.22 & 0.10 & 0.37 \\
$2001-2005$ & 0.26 & 0.10 & 0.25 & 0.13 & 0.39 \\
$2002-2006$ & 0.38 & 0.33 & 0.43 & 0.41 & 0.35 \\
$2003-2007$ & 0.56 & 0.58 & 0.63 & 0.71 & 0.47 \\
$2004-2008$ & 0.52 & 0.53 & 0.61 & 0.61 & 0.47 \\
$2005-2009$ & 0.70 & 0.71 & 0.77 & 0.75 & 0.62 \\
$2006-2010$ & 0.70 & 0.71 & 0.82 & 0.68 & 0.63 \\
$2007-2011$ & 0.70 & 0.69 & 0.84 & 0.68 & 0.68 \\
$2008-2012$ & 0.60 & 0.57 & 0.80 & 0.51 & 0.60 \\
$2009-2013$ & 0.49 & 0.48 & 0.73 & 0.36 & 0.42 \\
$2010-2014$ & 0.30 & 0.31 & 0.56 & 0.20 & 0.20 \\
$2011-2015$ & 0.04 & -0.04 & 0.06 & -0.26 & 0.07 \\
$2012-2016$ & -0.02 & -0.07 & 0.01 & -0.26 & 0.24 \\
$2013-2017$ & 0.19 & 0.06 & 0.23 & -0.17 & 0.33 \\
$2014-2018$ & 0.39 & 0.37 & 0.61 & 0.19 & 0.47 \\
$2015-2019$ & 0.55 & 0.56 & 0.72 & 0.46 & \\
\hline
\end{tabular}

Source: Own calculations, based on Macrobond.

\subsection{Nominal Integration}

There is some evidence that nominal developments became increasingly synchronized within both the EU and euro area. However, given that the union became increasingly asynchronous in real terms, such nominal alignment was probably not driven by purely economic forces, but predominantly by monetary policy efforts by the ECB to counteract centrifugal real economic forces.

Over the entire observation period, the correlation coefficients of both headline and especially core inflation (excluding thus energy and food prices, characterized by volatile price developments) increased - albeit not steadily - for the EU as a whole and the euro area (Tables 7 and 8). Especially euro peripheral countries moved closer to the rest of the euro area. However, euro core countries are a remarkable exception here, particularly regarding the core inflation rate. It seems that core consumer prices on average in this group of countries were never synchronized with the euro area developments. This finding is in line with the previous literature (Carney 2017; Álvarez et al. 2020) ${ }^{9}$ and constitutes a remarkable hurdle in monetary policy making, given the role played by the core inflation rate in the assessment of the underlying dynamics of consumer prices. 
Table 7. Headline inflation rate-averages of country-level correlation coefficients for different country groups.

\begin{tabular}{cccccc}
\hline & EU & Euro & Euro Core & Euro Periphery & EU Non-Euro \\
\hline $2000-2004$ & 0.44 & 0.46 & 0.40 & 0.55 & 0.38 \\
$2001-2005$ & 0.45 & 0.47 & 0.39 & 0.57 & 0.37 \\
$2002-2006$ & 0.41 & 0.43 & 0.32 & 0.50 & 0.32 \\
$2003-2007$ & 0.46 & 0.48 & 0.39 & 0.59 & 0.43 \\
$2004-2008$ & 0.60 & 0.63 & 0.59 & 0.76 & 0.58 \\
$2005-2009$ & 0.61 & 0.63 & 0.61 & 0.80 & 0.63 \\
$2006-2010$ & 0.61 & 0.63 & 0.64 & 0.80 & 0.63 \\
$2007-2011$ & 0.62 & 0.63 & 0.66 & 0.78 & 0.65 \\
$2008-2012$ & 0.62 & 0.62 & 0.69 & 0.73 & 0.64 \\
$2009-2013$ & 0.49 & 0.48 & 0.57 & 0.58 & 0.55 \\
$2010-2014$ & 0.54 & 0.54 & 0.61 & 0.56 & 0.56 \\
$2011-2015$ & 0.59 & 0.62 & 0.60 & 0.63 & 0.61 \\
$2012-2016$ & 0.58 & 0.60 & 0.53 & 0.63 & 0.53 \\
$2013-2017$ & 0.55 & 0.57 & 0.37 & 0.66 & 0.44 \\
$2014-2018$ & 0.62 & 0.64 & 0.42 & 0.74 & 0.54 \\
$2015-2019$ & 0.61 & 0.64 & 0.41 & 0.75 & 0.54 \\
\hline
\end{tabular}

Source: Own calculations, based on Macrobond.

Table 8. Core inflation rate-averages of country-level correlation coefficients for different country groups.

\begin{tabular}{cccccc}
\hline & EU & Euro & Euro Core & Euro Periphery & EU Non-Euro \\
\hline $2000-2004$ & 0.13 & 0.12 & -0.10 & 0.61 & 0.08 \\
$2001-2005$ & 0.18 & 0.17 & -0.10 & 0.70 & 0.09 \\
$2002-2006$ & 0.19 & 0.20 & -0.11 & 0.64 & 0.13 \\
$2003-2007$ & 0.22 & 0.23 & -0.06 & 0.60 & 0.13 \\
$2004-2008$ & 0.23 & 0.23 & -0.04 & 0.60 & 0.04 \\
$2005-2009$ & 0.18 & 0.21 & -0.04 & 0.63 & -0.01 \\
$2006-2010$ & 0.18 & 0.21 & -0.01 & 0.57 & -0.06 \\
$2007-2011$ & 0.14 & 0.17 & -0.07 & 0.51 & -0.04 \\
$2008-2012$ & 0.10 & 0.14 & -0.08 & 0.42 & 0.10 \\
$2009-2013$ & 0.11 & 0.14 & -0.11 & 0.41 & 0.19 \\
$2010-2014$ & 0.19 & 0.18 & -0.10 & 0.31 & 0.25 \\
$2011-2015$ & 0.23 & 0.22 & -0.16 & 0.38 & 0.37 \\
$2012-2016$ & 0.27 & 0.27 & -0.16 & 0.44 & 0.42 \\
$2013-2017$ & 0.38 & 0.40 & -0.02 & 0.59 & 0.47 \\
$2014-2018$ & 0.43 & 0.46 & 0.01 & 0.64 & 0.45 \\
$2015-2019$ & 0.51 & 0.55 & 0.18 & 0.67 & \\
\hline
\end{tabular}

Source: Own calculations, based on Macrobond.

Finally, the political commitment of the ECB to save the euro-and implicitly also the EU-at any price is reflected in the rising correlation coefficients for 10-year government bond yields (Table 9). The various monetary policy interventions implemented since the Great Financial Crisis, ranging from maintaining low policy interest rates, through different security buying programmes, to longer term refinancing operations for banks, had the likely effect of reducing financial volatility within the system. Indeed, interest rates moved very close together in the recent years across the euro area and-through spillover effects-also across the entire EU. However, a note regarding the euro periphery is still due here. The lower correlation coefficients observed in this country group, especially in the aftermath of the European debt crisis, are due to specific circumstances (i.e., debt default) in Greece. Upon exclusion of this country from the calculation, alignment of interest rates of Euro periphery is comparably high as in Euro core. 
Table 9. Yields on 10-year government bond-average of country-level correlation coefficients for different country groups.

\begin{tabular}{lcccccc}
\hline & EU & Euro & $\begin{array}{c}\text { Euro } \\
\text { Core }\end{array}$ & $\begin{array}{c}\text { Euro } \\
\text { Periphery }\end{array}$ & $\begin{array}{c}\text { Euro Periphery } \\
\text { ex. Greece }\end{array}$ & EU Non-Euro \\
\hline $2000-2004$ & 0.63 & 0.71 & 0.99 & 0.96 & 0.99 & 0.50 \\
$2001-2005$ & 0.68 & 0.79 & 1.00 & 0.98 & 0.99 & 0.47 \\
$2002-2006$ & 0.65 & 0.75 & 0.99 & 0.97 & 0.98 & 0.46 \\
$2003-2007$ & 0.60 & 0.68 & 0.99 & 0.78 & 0.91 & 0.38 \\
$2004-2008$ & 0.59 & 0.64 & 0.97 & 0.61 & 0.80 & 0.42 \\
$2005-2009$ & 0.57 & 0.61 & 0.94 & 0.57 & 0.72 & 0.49 \\
$2006-2010$ & 0.51 & 0.58 & 0.88 & 0.59 & 0.69 & 0.34 \\
$2007-2011$ & 0.42 & 0.52 & 0.61 & 0.72 & 0.76 & 0.20 \\
$2008-2012$ & 0.35 & 0.42 & 0.32 & 0.71 & 0.74 & 0.21 \\
$2009-2013$ & 0.35 & 0.40 & 0.28 & 0.69 & 0.73 & 0.23 \\
$2010-2014$ & 0.46 & 0.47 & 0.36 & 0.73 & 0.77 & 0.48 \\
$2011-2015$ & 0.53 & 0.51 & 0.42 & 0.74 & 0.80 & 0.59 \\
$2012-2016$ & 0.54 & 0.55 & 0.44 & 0.74 & 0.85 & 0.52 \\
$2013-2017$ & 0.62 & 0.63 & 0.84 & 0.59 & 0.82 & 0.62 \\
$2014-2018$ & 0.70 & 0.71 & 0.89 & 0.71 & 0.88 & 0.68 \\
$2015-2019$ & 0.71 & 0.73 & 0.94 & 0.65 & 0.86 & 0.68 \\
\hline
\end{tabular}

Source: Own calculations, based on Macrobond.

Unfortunately, there is little indication that the relatively high degree of symmetry in interest rate developments and the underlying favourable refinancing conditions were supportive in removing the fundamental weaknesses in real economic conditions. The asymmetries in the cyclical development remain and are in some areas even stronger, particularly between the euro area members than between non-euro countries. The struggle to translate favourable capital market conditions into improvement of real economic conditions is potentially strengthened by the moral hazard incentives which are indigenous in currency areas and in most of its unconventional instruments of common monetary policy (Issing 2011; Belke 2013; Eijffinger and Hoogduin 2018). The rapidly increasing indebtedness across the euro area is an indication of this phenomenon.

\section{Business Cycle Alignment According to Instantaneous Quasi-Correlations}

The rolling Pearson correlations, which we adopted as our baseline computational method and which is extensively used by the literature measuring cyclical co-movement between countries, have the advantage of consistently showing the underlying trend in the co-movements. At the same time, given the presence of overlapping observations over the sample, this procedure introduces autocorrelation in the underlying time series.

To overcome the aforementioned drawback, Morgan et al. (2004) developed the so called instantaneous quasi-correlation measure. ${ }^{10}$ Adopted to our framework, this measure has the following general form:

$$
q r_{i}=\frac{\left(x_{i t}-\bar{x}_{i}\right)\left(y_{i t}-\bar{y}_{i}\right)}{\sigma_{i}^{x} \sigma_{i}^{y}}
$$

where $x_{i t}$ is the value of indicator (e.g., growth rate of real GDP) in country i at time $t$, whereas $\bar{x}_{i}$ and $\sigma_{i}^{x}$ are the mean and standard deviation of the indicator, respectively, over the sample period. Finally, $y_{i t}$ refers to the value of the same indicator in the relevant country aggregate for country $i$ at time $t$, whereas $\bar{y}_{i}$ and $\sigma_{i}^{y}$ are the respective values of the relevant country aggregate.

There are some advantages of this method (Duval et al. 2014). In particular, it makes possible to determine co-movements at single point in time rather than over a time interval. At the same time, it has desirable statistical properties. Most importantly, the period mean of the measure is deemed to converge to the standard Pearson correlation coefficient. ${ }^{11}$ 
In Table 10, we report the results of instantaneous quasi-correlations for real GDP growth rates. ${ }^{12}$ Additionally, Figure 4 shows the pattern of development of the measure in the main country groups, the EU as a whole and the Euro members. Generally, the numbers tend to confirm the picture obtained with the rolling Pearson correlations. All country groups tended to be slightly more synchronized in the years before the 2008 crisis, but there was barely any improvement in the period after the crisis.

Table 10. Instantaneous quasi-correlations for real GDP growth rates-average of country-level correlation coefficients for different country groups.

\begin{tabular}{cccccc}
\hline & EU & Euro & Euro Core & Euro Periphery & EU Non-Euro \\
\hline 2004 & 0.00 & -0.02 & 0.00 & 0.01 & 0.02 \\
2005 & 0.06 & 0.05 & 0.02 & 0.00 & 0.04 \\
2006 & 0.22 & 0.36 & 0.23 & 0.30 & 0.20 \\
2007 & 0.26 & 0.20 & 0.16 & 0.15 & 0.18 \\
2008 & 1.16 & 1.10 & 0.94 & 0.90 & 1.20 \\
2009 & 2.66 & 3.33 & 2.74 & 1.89 & 2.23 \\
2010 & 0.21 & 0.27 & 0.38 & 0.00 & 0.18 \\
2011 & 0.07 & 0.08 & 0.13 & 0.01 & 0.09 \\
2012 & 0.16 & 0.15 & 0.14 & 0.18 & 0.19 \\
2013 & 0.04 & 0.07 & 0.07 & 0.14 & 0.00 \\
2014 & 0.00 & -0.01 & -0.02 & -0.02 & 0.00 \\
2015 & 0.01 & -0.02 & -0.03 & -0.07 & 0.01 \\
2016 & 0.05 & 0.04 & 0.04 & 0.00 & 0.03 \\
2017 & 0.09 & 0.10 & 0.12 & -0.01 & 0.09 \\
2018 & 0.06 & 0.05 & 0.03 & 0.05 & 0.07 \\
2019 & 0.11 & 0.05 & 0.05 & 0.03 & 0.16 \\
\hline
\end{tabular}

Source: Own calculations, based on Macrobond.

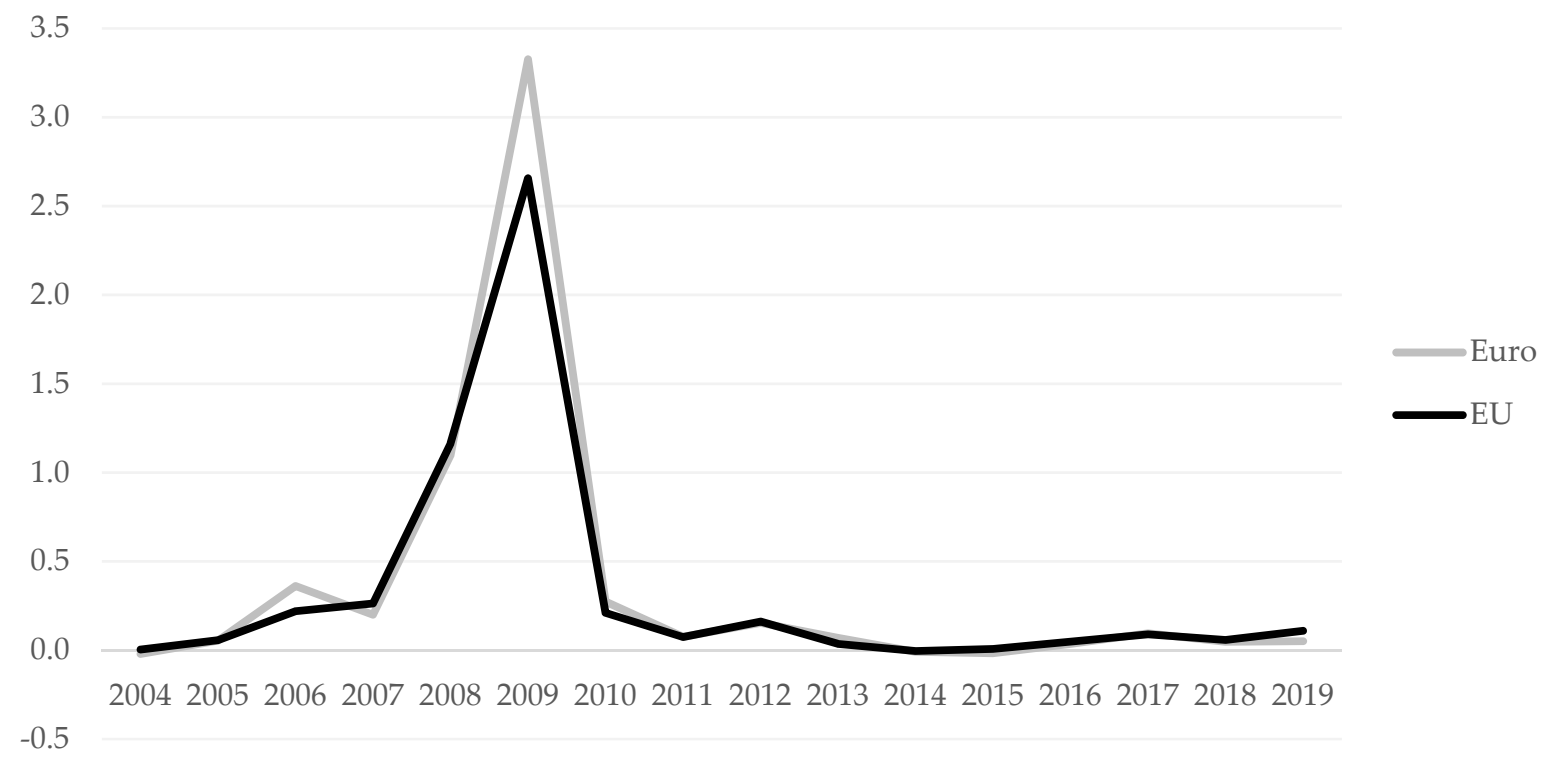

Figure 4. Business cycle synchronization (in terms of real GDP growth) measured with instantaneous quasi-correlations. Source: Own calculations, based on Macrobond.

An important observation at this point regards the values of the coefficients peaking during the crises (Figure 4). This is a well-known phenomenon in the dedicated literature. Indeed, an analogous pattern was detected by Duval et al. (2014) and Zamani and Tayebi (2013). Both studies confirm that (1) during normal times, business cycle synchronization has been much smaller and (2) that large spikes in business cycle synchronization occurred around the Asian crisis of the late 1990s and around global financial crisis in 2008. Finally, 
Duval et al. (2014) confirm our finding that similar results could be obtained using the standard Pearson correlation coefficients.

\section{Policy Implications}

Most of our indicators show low and/or declining business cycle correlations among the members of the EU, the euro area and the various sub-groups. Obviously, the comovement of business cycles increased during the years of the financial crisis and the sovereign debt crisis. However, the process weakened gradually in the years following the crisis, leading to zero or even negative correlation coefficients once the crisis years are left out. Thus, in terms of business cycle symmetry, even two decades of EMU were eventually not enough to move the euro area closer to an OCA ex post. In the same vein, there is no evidence that economic alignment in the euro area is higher than between non-euro member states. So far, the endogeneity hypothesis of OCA does not hold.

Correlation coefficients are generally lower among indicators that capture real economic alignment. At the same time, albeit being pushed by the ECB, nominal integration shows heterogeneous developments among the member states as well. This is especially true for core inflation. Large differences prevail between the core and the periphery of the euro area. This heterogeneity makes it almost impossible for the ECB's monetary policy to adequately address the individual economic developments of its member states. In this regard, estimations by the German Council of Economic Experts show that between 2000 and 2007 the ECB's interest rate for its main refinancing operations was too low for Spain, Italy and France and too high for Germany when compared with the estimated Taylor (1993) rates for those countries (German Council of Economic Experts GCEE). In the years following the financial crisis up to 2016, the ECB policy rate was too high for the Euro periphery and too low for the Euro core. From 2017 onwards, the ECB's monetary policy was too expansionary for almost all euro area countries.

Over the recent years, efforts have been increased to advance an ever-deeper integration, with the aim at preventing that economic disintegration would unleash political forces working against the union. At least three strategies are being implicitly pursued in parallel:

(1) Efforts to enhance structural adjustment of the member states,

(2) European Central Bank (ECB) as lender of last resort,

(3) Fiscal union with mutualisation of (public) debt. ${ }^{13}$

Within the first strategy, different instruments have been promoted so far to support national governments in pursuing the necessary structural adjustments. Among them, the so-called European Semester is aimed at coordinating single member's economic policies, by preventing excessive macroeconomic imbalances across the EU, by ensuring that structural reforms are implemented and by boosting investment. It gives the EU member states country-specific recommendations (CSRs) regarding their public budgets and their broader economic and social policies, with the aim at enhancing policy coordination among the member states. While this first strategy could be viewed as the economically most meaningful way to achieve a lasting cohesion of the union, the results discussed above suggest that its impact has been limited. Moreover, for a variety of reasons, economic policy coordination and enforcement is difficult to achieve (Alcidi and Gros 2017).

So far, the experience with the European Semester is rather disappointing, as Figure 5 illustrates. Since the introduction of the European Semester in 2011, only eleven reform proposals out of 993 assessed CSRs have been "fully implemented". Likewise, there has been hardly any "substantial progress" in following CSRs. Especially since 2015, the year the ECB started to boost its Asset Purchase Programme (APP), the member states' reform intensity appears to be extremely low. Consequently, the focus has shifted to the other two aforementioned strategies. 


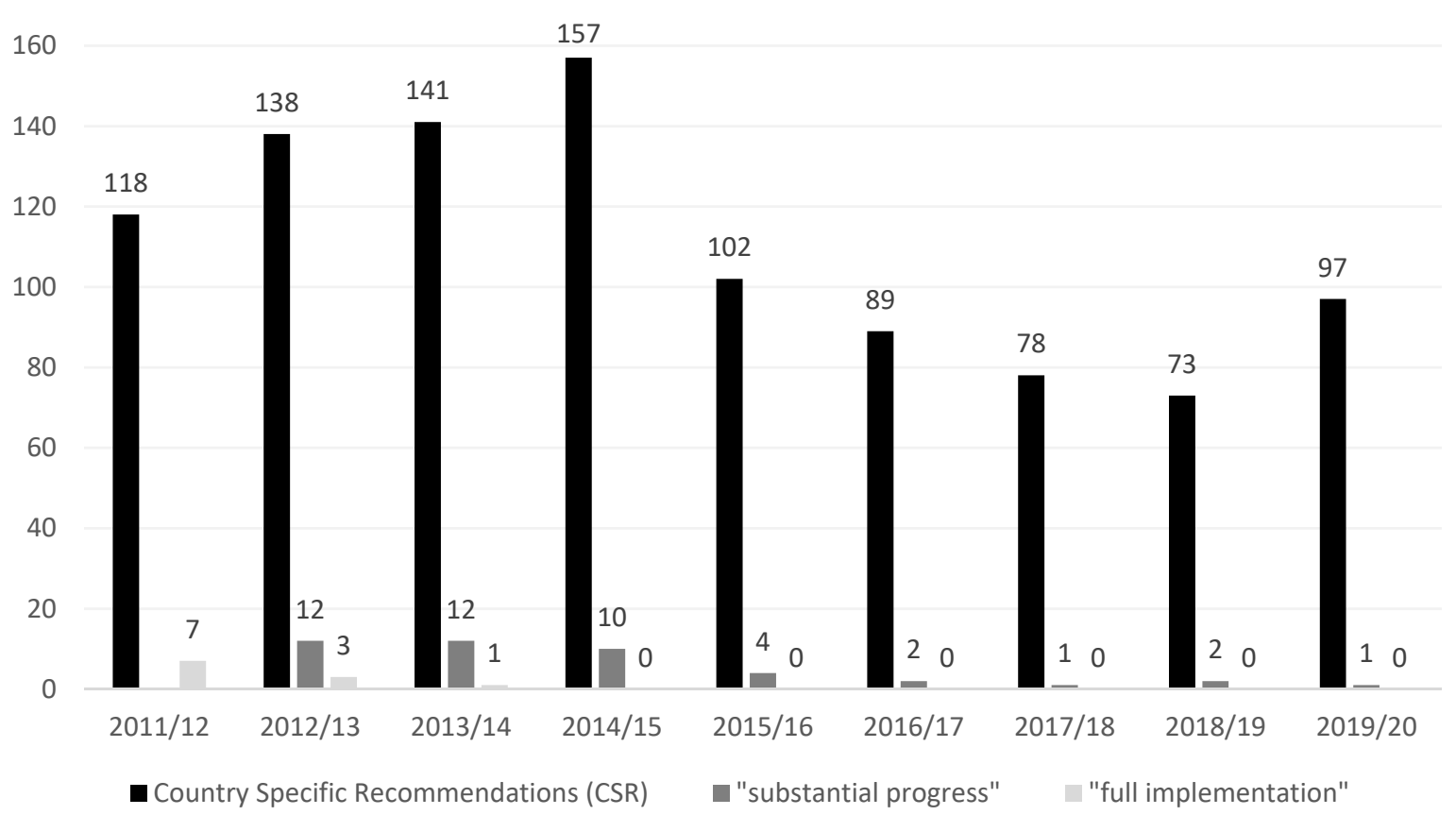

Figure 5. Responsiveness to reform proposals in the framework of the European Semester. Source: European Commission, König (2020).

The second strategy, related to rendering the ECB as the lender of last resort, is regarded as particularly attractive for highly indebted members of the euro area, which so far issue debt in a currency, over which they do not have a direct control. It is often argued that if the ECB were obliged to provide unlimited liquidity not only to banks but also to governments, this would provide bondholders an implicit insurance against the default of sovereign debtors, thereby reducing the fragility of the monetary union. Indeed, extensive monetary financing of distressed states, banks, companies or private households can - at least temporary - neutralize the disciplinary role of financial markets that became evident during the euro crisis of 2010-2012. However, it is questionable that circumventing the prohibition of monetary financing in the euro area and neutralizing market discipline would provide economic and fiscal stability in the long run. It is more likely that this perpetuates incentives for excessive public debt financing.

The Securities Markets Programme (SMP) of the ECB between 2010 and 2012 may be seen as a first step towards the ECB serving as a lender of last resort (see Figure 6). Under the SMP, the Eurosystem central banks bought selected government bonds from the Euro area crisis states (Greece, Italy, Portugal, Spain and Ireland) with a peak value of $€ 210$ billion, leading to a sharp reduction in bond yields of these countries. Since then, the ECB has launched several purchase programmes and has become the biggest creditor to the euro countries.

Following up on ECB President Draghi's promise to do "whatever it takes" to protect the euro, the ECB strengthened further its role of lender of last resort to governments (Wyplosz 2012; Buiter and Rahbari 2012a, 2012b). It formally committed itself to purchase unlimited amounts of selected government bonds in crisis situations under the conditions of the so-called Outright Monetary Transactions (OMT) programme. Although OMT has not been activated so far, there are serious concerns that the ECB clearly dismantled the boundaries of its monetary policy mandate (Kreis 2016). 


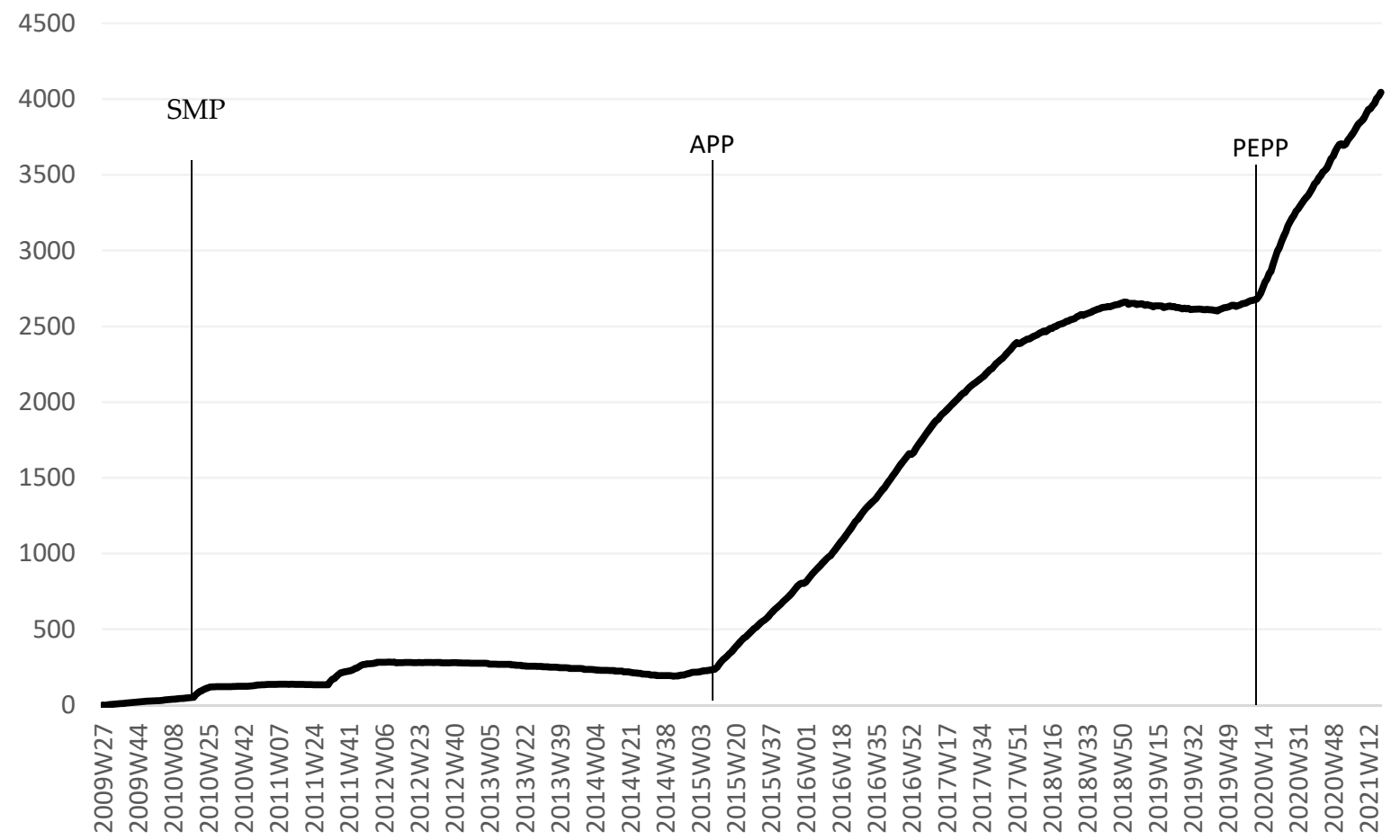

Figure 6. Eurosystem-Securities held for monetary policy purposes, in billions of Euro. Note: SMP-Securities Market Programme, APP—Asset Purchase Programme, PEPP—Pandemic Emergency Purchase Programme. Source: ECB, Statistical Data Warehouse.

Despite reasonable economic and legal concerns, a crucial condition of this strategy to work is that the central bank's commitment to act is never questioned by investors. However, there are several ways in which a loss of credibility of action might occur. It might come from outside due to deteriorating fundamentals or unsustainable fiscal stances of governments. Or it might be sparked by excessive inflationary pressures upon a substantial increase in liquidity in the system. The current strong expansion of money supply due to massive asset purchases by the ECB under the new Pandemic Emergency Purchase Program (PEPP), combined with limited practical options to withdraw liquidity at will, makes this scenario in the mid- to long-run increasingly likely (Weidman 2021).Whereas the second strategy could be implemented almost unilaterally by the ECB (practically not legally), the third strategy, consisting in efforts to establish a fiscal union, is more cumbersome, as it requires reaching consensus on political matters. Indeed, given that establishing a fiscal union would imply permanent transfers of financial resources from stronger to weaker members, opposition in the less-indebted countries still prevents the EMU to be transformed to a full "transfer union". For that reason, the proponents of this strategy have opted for a step-by-step introduction of elements of a transfer union by stealth.

A substantial step towards fiscal union was made with the common $€ 750$ billion debt issuance under the recent EU post-pandemic recovery fund "Next Generation EU" (NGEU). The fund will be financed by debt issued by the EU but backed by guarantees of the member states. It is important to note that NGEU has a strong redistributive component. The fund redistributes the majority of financial resources (70 percent) from member states with high levels of GDP per capita and employment to less affluent countries. Only 30 percent of the NGEU's financial assistance will be redistributed across countries according to their respective economic losses due to the COVID-19 pandemic. Thus, NGEU may be rather considered an extension of the existing cohesion policies. Accordingly, the EU members will benefit from the fund very differently (see Figure 7). In fact, most of the NGEU grants and loans will be distributed to Southern and Eastern Europe, with Italy 
(EUR 202 billion), Spain (EUR 157 billion) and Poland (EUR 64 billion) receiving the largest share of financial assistance. The actual pay-out of the financial assistance depends upon the approval of the member states' national recovery and resilience plans, setting out their reform and investment agenda for the next years. The plans are assessed by the European Commission, mainly based on consistency with the CSRs of the European Semester.

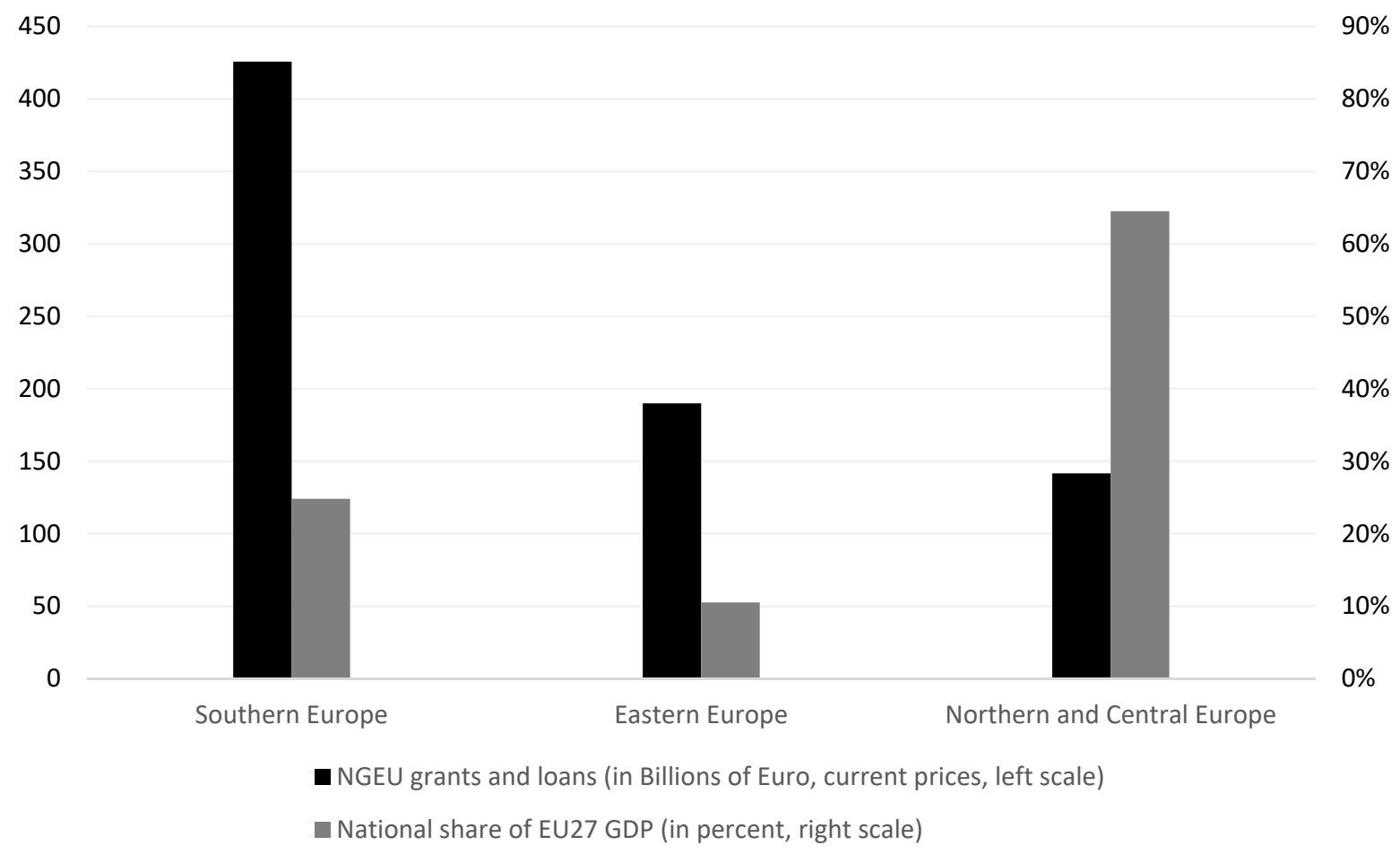

Figure 7. NextGenerationEU (NGEU)—distribution and liability. Notes: Southern Europe: IT, ES, EL, PT, MT, CY. Eastern Europe: BG, HR, CZ, HU, EE, LV, LT, PL, RO, SI, SK. Northern and Central Europe: DE, FR, AT, BE, IE, DK, FI, LX, NE, SE. We assume that all EU member states apply for NGEU grants. We further assume that only those 17 countries that applied for the EU's SURE loan facility will borrow from NGEU. Source: European Commission, own calculations.

Although the common debt issuance is explicitly designed as a one-off event, NGEU proponents regard it as an important step towards the creation of a fiscal union and classify it as a "Hamilton moment", mutualizing sovereign debt in the way the U.S. did more than 200 years ago. In fact, by allowing the EU level to issue common European bonds to fund national public expenditure, a longstanding taboo has been shattered. Especially the governments of the highly indebted member states of Southern Europe have been trying to establish Eurobonds for many times. However, since the new common debt issuance is limited in time and scope, to repeat or extend the new debt issuance will require unanimous support among the EU members. Whether this hurdle may be overcome will most likely depend on the success of NGEU spending. Given the low responsiveness rate to the European Semester and its CSRs so far, a success of NGEU is all but certain.

Critics of common European bonds regard them as a threat to solid public finances since liability and control lie in different hands. The resistance is explained on the ground of the aforementioned moral hazard risk, deriving from the incentive for countries to rely on the implicit insurance offered at the union's level (Herzog 2020; Kalamov and Staal 2020). Likewise, NGEU could serve as a precedent for shifting costs of future national crises to the EU level and redistribute them from weaker to stronger member countries. So far, EU debt does not count to national debt, thereby enabling member states to circumvent fiscal rules and making it more attractive for national governments to use NGEU finances instead of own resources. If recipients see the new funding as an opportunity to substitute domestically funded public investment, the principle of additionality would be 
undermined. The German recovery and resilience plan indicates that the concern regarding additionality is not unjustified as more than 80 percent of the newly outlined measures have already been part of the June 2020 stimulus package (German Council of Economic Experts GCEE).

Instead of transforming the EU to a fiscal union or the ECB to a lender of last resort, the EU could intensify its efforts to develop EMU towards an optimum currency area through deeper market integration and by avoiding measures that induce moral hazard. A deep and flexible EU single market could serve as a catalyst for the co-movement of business cycles and as an automatic stabilizer and shock absorber. Less moral hazard could lead to more discipline in markets and among policy makers. This could, in turn, contribute to more structural reforms and economic alignment in EMU.

\section{Conclusions}

The European Economic and Monetary Union is still far from being an optimal currency area. Our data-based analysis suggests that the previous integration efforts have not brought meaningful improvement in this matter. Indeed, most of our indicators show declining and very low correlation coefficients and heterogeneous integration levels across the member states. It seems that the European debt crisis halted the economic integration within the European Union and-even more so-within the euro area. Since the ECB can to a large extent intervene only with "one-size-fits-all" monetary policy instruments, this renders increasingly cumbersome the conduct of stabilisation policies within the euro area. At the same time, also the prospects for an enlarged monetary union are blurred, given the low degree of economic alignment of the prospective euro members.

As a matter of facts, different economic policy measures are already in place to correct for imperfect integration outcomes. Without the underlying strong political commitment to the union originating from the single member countries, the survival chances for the union would be much lower. Already in 2010-2012, EMU faced massive centrifugal financial forces. The repositioning of the European Central Bank as a financier of endangered entities has neutralized the disciplinary role of financial markets and re-equilibrated the survival risks of the common currency - with all known side effects. Currently, the stepwise creation of a fiscal union is supposed to strengthen the efforts to counteract the lack of economic alignment within euro area and the EU. However, given the risk that recipient countries might not use transfers in a way to increase economic efficiency so as to reduce economic misalignments, tensions within the union might eventually intensify.

Based on this, the need to better understand the determinants of economic alignments and consequences of the lack thereof is evident. Further research should aim at clarifying these issues and thus at formulating sound policy options for the future of the European integration process.

Author Contributions: Both authors contributed to all sections. Both authors have read and agreed to the published version of the manuscript.

Funding: This research received no external funding.

Institutional Review Board Statement: Not applicable.

Informed Consent Statement: Not applicable.

Data Availability Statement: Not applicable.

Conflicts of Interest: The authors declare no conflict of interest.

\section{Notes}

1 Nominal integration in terms of prices and interest rates is less vital as a precondition for a well-functioning currency union and should rather be the consequence of real integration (Buiter 2004; De Grauwe and Schnabl 2005).

2 For a comprehensive literature review on the business cycle synchronization in the first years of the euro area, see De Haan et al. (2008). 
3 Duarte and Gehringer (2020) show that stronger cyclical alignment could contribute to real convergence if average growth rates increased more in poorer than in richer countries. On the other hand, countries may converge to one another even if their business cycles were fully desynchronized, provided that, again, growth rates in poorer countries are on average higher than in richer countries over a longer time period. See also Belke et al. (2017) on the differences in the amplitude of business cycles in the euro area.

4 In developing their EU-Index, König and Ohr (2013) consider four different dimensions of integration, namely EU single market, EU homogeneity (convergence), EU symmetry and EU (legal and institutional) conformity. We focus on EU symmetry, since it constitutes a crucial economic precondition for an area forming a monetary union.

$5 \quad$ We use the Hodrick and Prescott (1981) decomposition, with lambda $=1600$ to detrend our time series. There are arguments for and against using this detrending method (see Hamilton (2017) and Hodrick (2020) for the two opposite views). Whereas other methods, for instance, based on phase-average-trend method, or on Baxter-King, or Christiano-Fitzgerald filters were developed, the findings by Nilsson and Gyomai (2011) suggest that the Hodrick-Prescott filter outperforms the others.

6 EU refers to $27 \mathrm{EU}$ members (EU-28 excluding Luxembourg, but including the UK). Euro includes 18 Euro countries. Euro core is the average across Austria, Belgium, Finland, France, Germany and the Netherlands and Euro periphery refers to Greece, Ireland, Italy, Portugal and Spain. EU non-euro includes EU member countries currently not participating in the euro-area, but formally obliged to once join the monetary union, namely, Bulgaria, Croatia, Czech Republic, Denmark, Hungary, Poland, Romania, and Sweden.

$7 \quad$ All single-country correlation coefficients are available upon request.

8 We focus here on Southern euro area members, rather than on Euro periphery as before, given that Ireland managed to break the negative public debt spiral in the aftermath of the European sovereign debt crisis.

9 An explanation for this suggests the existence of country-specific factors, such as timing of seasonal sales, the size of discounts applied on sales articles, as well as differences in quality adjustment procedures (Álvarez et al. 2020).

10 This measure was used in recent business cycle literature, for instance, in Alter et al. (2018), Duval et al. (2016), Abiad et al. (2013) and Kalemli-Özcan et al. (2013).

11 Additionally, the measure is not bounded between -1 and 1 , as the Pearson correlation is.

12 For brevity, we do not show the results for other indicators, but they are available upon request.

13 For a textbook elaboration of these strategies, see Chapter 6 in De Grauwe (2018).

\section{References}

Abiad, Abdul Davide Furceri, Sebnem Kalemli-Ozcan, and Andrea Pescatori. 2013. Dancing Together? Spillovers, Common Shocks, and the Role of Financial and Trade Linkages. World Economic Outlook. Washington, DC: International Monetary Fund, pp. 81-111.

Alcidi, Cinzia, and Daniel Gros. 2017. How to Strengthen the European Semester? CEPS Research Report No. 2017/15. Available online: https:/ / www.ceps.eu/ceps-publications/how-strengthen-european-semester/ (accessed on 10 March 2021).

Altavilla, Carlo. 2004. Do EMU Members Share the Same Business Cycle? Journal of Common Market Studies 42: 869-96. [CrossRef]

Alter, Adrian, Jane Dokko, and Dulani Seneviratne. 2018. House Price Synchronicity, Banking Integration, and Global Financial Conditions. IMF Working Paper WP/18/250. Washington, DC: International Monetary Fund.

Álvarez, Luis Julián, Maria Dolores Gadea, and Ana Gómez-Loscos. 2020. Inflation Comovements in Advanced Economies: Facts and Drivers. The World Economy 44: 485-509. [CrossRef]

Antonakakis, Nikolaos, and Gabriele Tondl. 2014. Does Integration and Economic Policy Coordination Promote Business Cycle Synchronization in the EU? Empirica 41: 541-75. [CrossRef]

Babetskii, Ian. 2005. Trade Integration and Synchronization of Shocks: Implications for EU Enlargement. Economics of Transition 13: 105-38. [CrossRef]

Badinger, Harald. 2005. Growth Effects of Economic Integration: Evidence from the EU Member States. Review of World Economics 141: 50-78. [CrossRef]

Balassa, Bela. 1961. The Theory of Economic Integration. Homewood: Irwin.

Baldwin, Richard. 2006. In or Out: Does It Matter? An Evidence-Based Analysis of the Euro's Trade Effects. London: Centre for Economic Policy Research (CERP), Available online: https:/ / cepr.org/sites/default/files/geneva_reports/GenevaP178.pdf (accessed on 30 March 2021).

Beck, Krzysztof. 2019. What Drives Business Cycle Synchronization? BMA Results from the European Union. Baltic Journal of Economics 19: 248-75. [CrossRef]

Belke, Ansgar. 2013. Finance Access of SMEs: What Role for the ECB? Ruhr Economic Papers No. 430. Bochum: Ruhr-Universität Bochum (RUB), Available online: https://www.rwi-essen.de/media/content/pages/publikationen/ruhr-economic-papers/REP_13_4 30.pdf (accessed on 17 February 2021).

Belke, Ansgar, Clemens Domnick, and Daniel Gros. 2017. Business Cycle Synchronization in the EMU: Core vs. Periphery. Open Economies Review 28: 863-92. [CrossRef]

Bolea, Lucía, Rosa Duarte, and Julio Sánchez Chóliz. 2018. From Convergence to Divergence? Some New Insights into the Evolution of the European Union. Structural Change and Economic Dynamics 47: 82-95. [CrossRef] 
Buiter, Willelm. 2004. To Purgatory and Beyond: When and How Should the Accession Countries from Central and Eastern Europe Become Full Members of EMU? CEPR Discussion Paper Series 4342. London: Centre for Economic Policy Research (CERP), Available online: https:/ / repec.cepr.org/repec/cpr/ceprdp/DP4342.pdf (accessed on 21 April 2021).

Buiter, Willem, and Ebrahim Rahbari. 2012a. Looking into the Deep Pockets of the ECB. Citi Global Economics View. February 27. Available online: http://blogs.ft.com/money-supply/files/2012/02/citi-Looking-into-the-Deep-Pockets-of-the-ECB.pdf (accessed on 19 February 2021).

Buiter, Willem, and Ebrahim Rahbari. 2012b. The ECB as Lender of Last Resort for Sovereigns in the Euro Area. Journal of Common Market Studies 50: 6-35. [CrossRef]

Bulmer, Simon. 2007. History and Institutions. In The Economics of the European Union. Edited by Michael Artis, Mike Artis and Frederick Nixson. Oxford: Oxford University Press, pp. 5-34.

Camacho, Maximo, Angela Caro, and German Lopez-Buenache. 2020. The Two-Speed Europe in Business Cycle Synchronization. Empirical Economics 59: 1069-84. [CrossRef]

Campos, Nauro, Jarko Fidrmuc, and Iikka Korhonen. 2019. Business Cycle Synchronization and Currency Unions: A Review of the Econometric Evidence Using Meta-Analysis. International Review of Financial Analysis 61: 274-83. [CrossRef]

Carney, Mark. 2017. [De]Globalisation and Inflation. Speech Given at the 2017 IMF Michel Camdessus Central Banking Lecture. Available online: https:/ / www.bankofengland.co.uk/-/media/boe/files/speech/2017/de-globalisation-and-inflation.pdf (accessed on 21 April 2021).

Cecchini, Paolo, Michael Catinat, and Alexis Jacquemin. 1988. The Benefits of a Single Market. Aldershot: Wildwood House.

Clarida, Richard, Jordi Gali, and Mark Gertler. 1999. The Science of Monetary Policy: A New Keynesian Perspective. Journal of Economic Literature 37: 1661-707. [CrossRef]

Darvas, Zsolt, and György Szapáry. 2008. Business Cycle Synchronization in the Enlarged EU. Open Economies Review 19: 1-19. [CrossRef]

De Grauwe, Paul. 2018. Economics of Monetary Union, 10th ed. New York: Oxford University Press.

De Grauwe, Paul, and Gunther Schnabl. 2005. Nominal versus Real Convergence-EMU Entry Scenarios for the New Member States. Kyklos 4: 537-55. [CrossRef]

De Grauwe, Paul, and Yuemei Ji. 2016. Synchronisation in Business Cycles: An Endogenous Explanation. London: VoxEU, Available online: https:/ /voxeu.org/article/synchronisation-business-cycles (accessed on 19 April 2021).

De Haan, Jakob, Robert Inklaar, and Olaf Sleijpen. 2002. Have Business Cycles Become More Synchronized? Journal of Common Market Studies 40: 23-42. [CrossRef]

De Haan, Jakob, Robert Inklaar, and Richard Jong-A-Pin. 2008. Will Business Cycles in the Euro Area Converge? A Critical Survey of Empirical Research. Journal of Economic Surveys 22: 234-73. [CrossRef]

Degiannakis, Stavros, David Duffy, and George Filis. 2014. Business Cycle Synchronization in EU: A Time-Varying Approach. Scottish Journal of Political Economy 61: 348-70. [CrossRef]

Diaz del Hoyo, Juan Luis, Ettore Dorrucci, Frigyes Ferdinand Heinz, and Sona Muzikarova. 2017. Real Convergence in the Euro Area: A Long-Term Perspective. ECB Occasional Paper No. 203. Available online: https://www.ecb.europa.eu/pub/pdf/scpops/ecb.op2 03.en.pdf (accessed on 25 March 2021).

Dickerson, Andrew, Heather Gibson, and Euclid Tsakalotos. 1998. Business Cycle Correspondence in the European Union. Empirica 25: 49-75. [CrossRef]

Duarte, Pablo, and Agnieszka Gehringer. 2020. Disintegration versus Divergence: The EMU Experience. Macroeconomics 05/11/2020. Köln: Flossbach von Storch Research Institute, Available online: https://www.flossbachvonstorch-researchinstitute.com/ fileadmin/user_upload/RI/Studien/files/20201105-disintegration-versus-divergence.pdf (accessed on 19 March 2021).

Duval, Romain, Kevin Cheng, Kum Hwa Oh, Richa Saraf, and Dulani Seneviratne. 2014. Trade Integration and Business Cycle Synchronization: A Reappraisal with Focus on Asia. IMF Working Paper WP/14/32. Washington, DC: International Monetary Fund, Available online: https: / www.imf.org/en/Publications/WP/Issues/2016/12/31/Trade-Integration-and-Business-CycleSynchronization-A-Reappraisal-with-Focus-on-Asia-41460 (accessed on 15 March 2021).

Duval, Romain, Nan Li, Richa Saraf, and Dulani Seneviratne. 2016. Value-Added Trade and Business Cycle Synchronization. Journal of International Economics 99: 251-62. [CrossRef]

Eichengreen, Barry. 1991. Is Europe an Optimum Currency Area? NBER Working Paper No. 3579. Cambridge: National Bureau of Economic Research, Available online: https:/ / www.nber.org/system/files/working_papers/w3579/w3579.pdf (accessed on 21 January 2021).

Eijffinger, S., and L. Hoogduin. 2018. ECB: Quo Vadis? Intereconomics 3: 170-73. [CrossRef]

Engel, Charles, and John Rogers. 1996. How Wide is the Border? American Economic Review 86: 1113-25.

European Commission. 1985. Completing the Internal Market. White Paper from the Commission to the European Council (Milan, 28-29 June 1985), COM(85) 310. Available online: https:/ / eur-lex.europa.eu/legal-content/EN/TXT/PDF/?uri=CELEX: 51985DC0310\&from=EN (accessed on 10 February 2021).

European Commission. 1990. One Market, One Money: An Evaluation of the Potential Benefits and Costs of Forming an Economic and Monetary Union. European Economy 44. Brussels: Commission for the European Communities.

Filipovski, Vladimir, Predrag Trpeski, and Jane Bogoev. 2018. Business Cycle Synchronization of a Small Open EU-Candidate Country's Economy with the EU Economy. Panoeconomicus 65: 609-31. [CrossRef] 
Frankel, Jeffrey, and Andrew Rose. 1997. Is EMU More Justifiable Ex Post than Ex Ante. European Economic Review 41: 753-60. [CrossRef]

Frankel, Jeffrey, and Andrew Rose. 1998. The Endogeneity of the Optimum Currency Area Criteria. Economic Journal 108: 1009-25. [CrossRef]

Franks, Jeffrey, Bergljot Barkbu, Rodolphe Blavy, William Oman, and Hanni Schoelermann. 2018. Economic Convergence in the Euro Area: Coming Together or Drifting Apart? IMF Working Paper WP/18/10. Washington, DC: International Monetary Fund, Available online: https: / / www.imf.org/en/Publications/WP / Issues / 2018/01/23/Economic-Convergence-in-the-Euro-Area-ComingTogether-or-Drifting-Apart-45575 (accessed on 11 February 2021).

Gächter, Martin, and Alexandra Riedl. 2014. One Money, One Cycle? The EMU Experience. Journal of Macroeconomics 42: 141-55. [CrossRef]

Gächter, Martin, Alexandra Riedl, and Doris Ritzberger-Grünwald. 2012. Business Cycle Synchronization in the Euro Area and the Impact of the Financial Crisis. Monetary Policy and the Economy 2: 33-60.

Gehringer, Agnieszka. 2013. Growth, Productivity and Capital Accumulation: The Effects of Financial Liberalization in the Case of European Integration. International Review of Economics \& Finance 25: 291-309.

German Council of Economic Experts (GCEE). 2018. Setting the Right Course for Economic Policy. Annual Report 2018/19. Wiesbaden: German Council of Economic Experts, chp. 4. Available online: https: / www.sachverstaendigenrat-wirtschaft.de/en/ publications / annual-reports / previous-annual-reports/annual-report-201819.html (accessed on 16 March 2021).

German Council of Economic Experts (GCEE). 2021. Stellungnahme zum Entwurf des Deutschen Aufbau- und Resilienzplans von Dezember 2020. Available online: https://www.sachverstaendigenrat-wirtschaft.de/themen/produktivitaet/ produktivitaetsausschuss/stellungnahme-zum-deutschen-aufbau-und-resilienzplan-darp-veroeffentlicht-2404.html (accessed on 16 March 2021).

Gouveia, Sofia, and Leonida Correia. 2008. Business Cycle Synchronisation in the Euro Area: The Case of Small Countries. International Economics and Economic Policy 5: 103-21. [CrossRef]

Guerini, Mattia, Duc Thi Luu, and Mauro Napoletano. 2019. Synchronization Patterns in the European Union. GREDEG Working Paper No. 2019-30. Available online: https:/ / halshs.archives-ouvertes.fr/halshs-02375416/document (accessed on 16 March 2021).

Hamilton, James. 2017. Why You Should Never Use the Hodrick-Prescott Filter. NBER Working Paper No. 23429. Cambridge: National Bureau of Economic Research, Available online: https:/ / direct.mit.edu/rest/article/100/5/831/58479/Why-You-Should-NeverUse-the-Hodrick-Prescott (accessed on 15 March 2021).

Herzog, B. 2020. Corona-Bonds und EU-Verschuldung: Zukunftsvision oder Europäische Naivität? Zeitschrift für Wirtschaftspolitik 69: 148-65. [CrossRef]

Hodrick, Robert. 2020. An Exploitation of Trend-Cycle Decomposition Methodologies in Simulated Data. NBER Working Paper No. 26450. Cambridge: National Bureau of Economic Research, Available online: https:/ / www.nber.org/papers/w26750 (accessed on 15 March 2021).

Hodrick, Robert, and Edward Prescott. 1981. Postwar US Business Cycles: An Empirical Investigation. Discussion Paper No. 451. Evanston: Northwestern University, Center for Mathematical Studies in Economics and Management Science.

Issing, Otmar. 2011. Moral Hazard Will Result from ECB Bond Buying. Financial Times, November 30.

Kalamov, Zarko, and Klaas Staal. 2020. The Pitfalls and Possibilities of Coronabonds. LSE European Politics and Policy Blog, Available at LSE European Politics and Policy (EUROPP) Blog: The Pitfalls and Possibilities of Coronabonds. Available online: https:/ /blogs.lse.ac.uk/europpblog/2020/04/20/the-pitfalls-and-possibilities-of-coronabonds/ (accessed on 12 March 2021).

Kalemli-Özcan, Sebnem, Elias Papaioannou, and Fabrizio Perri. 2013. Global Banks and Crisis Transmission. Journal of International Economics 89: 495-510. [CrossRef]

Kenen, Peter. 1969. The Theory of Optimum Currency Areas: An Eclectic View. In Monetary Problems in the International Economy. Edited by Robert Mundell and Alexander Swoboda. Chicago: University of Chicago Press.

König, Jörg. 2020. EU-Stabilität nach Corona: Subsidiarität und Solidarität. Auf den Punkt 3. Berlin: Stiftung Marktwirtschaft.

König, Jörg, and Renate Ohr. 2013. Different Efforts in European Economic Integration: Implications of the EU Index. Journal of Common Market Studies 51: 1074-90. [CrossRef]

Konstantakopoulou, Ioanna, and Mike Tsionas. 2011. The Business Cycle in Eurozone Economies (1960 to 2009). Applied Finanancial Economics 21: 1495-513. [CrossRef]

Kreis, Kronberger. 2016. Dismantling the Boundaries of the ECB's Monetary Policy Mandate: The CJEU's OMT Judgement and Its Consequences. Kronberger Kreis Studien 61. Berlin: Stiftung Marktwirtschaft.

Krugman, Paul. 1979. Increasing Returns, Monopolistic Competition, and International Trade. Journal of International Economics 9: 469-79. [CrossRef]

Krugman, Paul. 1991a. Increasing Returns and Economic Geography. Journal of Political Economy 99: 183-99. [CrossRef]

Krugman, Paul. 1991b. Geography and Trade. Cambridge: MIT Press.

Krugman, Paul, Maurice Obstfeld, and Marc Melitz. 2018. International Economics: Theory and Policy. Harlow: Pearson Education Limited.

Lehwald, Sybille. 2013. Has the Euro Changed Business Cycle Synchronization? Evidence from the Core and the Periphery. Empirica 40: 655-84. [CrossRef] 
McCarthy, Mary, and Bent Sørensen. 2006. Comments on the Paper: Trends and Cycles in the Euro Area: How Much Heterogeneity and Should We Worry about It? ECB Working Paper No. 595. Frankfurt: European Central Bank, Available online: https: //www.ecb.europa.eu/pub/pdf/scpwps/ecbwp595.pdf (accessed on 10 May 2021).

McKinnon, Ronald. 1963. Optimum Currency Areas. American Economic Review 53: 717-25.

Miles, William, and Chu-Ping Vijverberg. 2018. Did the Euro Common Currency Increase or Decrease Business Cycle Synchronization for its Member Countries? Economica 85: 558-80. [CrossRef]

Morgan, Donald, Bertrand Rime, and Philip Strahan. 2004. Bank Integration and State Business Cycles. Quarterly Journal of Economics 119: 1555-85. [CrossRef]

Müller, Claudia, and Herbert Buscher. 1999. The Impact of Monetary Instruments on Shock Absorption in EU-Countries. ZEW Discussion Papers No. 99-15. Mannheim: ZEW, Available online: https://ftp.zew.de/pub/zew-docs/dp/dp1599.pdf (accessed on 10 May 2021).

Mundell, Robert. 1961. A Theory of Optimum Currency Areas. American Economic Review 51: 567-665.

Nikolov, Plamen. 2016. Cross-Border Risk Sharing after Asymmetric Shocks: Evidence from the Euro Area and the United States. Quarterly Report on the Euro Area (QREA), Directorate General Economic and Financial Affairs (DG ECFIN). Brussels: European Commission, vol. 15, pp. 7-18.

Nilsson, Ronny, and Gyorgy Gyomai. 2011. Cycle Extraction: A Comparison of the Phase-Average Trend Method, the Hodrick-Prescott and Christiano-Fitzgerald Filters. OECD Statistics Working Papers No. 2011/04. Paris: OECD Publishing. [CrossRef]

Notaro, Giovanni. 2011. Notaro, Giovanni 2011. European Integration and Productivity: Exploring the Early Effects of Completing the Internal Market. Journal of Common Market Studies 49: 845-69. [CrossRef]

Oman, William. 2019. The Synchronization of Business Cycles and Financial Cycles in the Euro Area. International Journal of Central Banking 15: 327-62.

Papageorgiou, Theofanis, Panayotis Michaelides, and John Milios. 2010. Business Cycles Synchronization and Clustering in Europe (1960-2009). Journal of Economics and Business 62: 419-70. [CrossRef]

Rogoff, Kenneth. 1985. The Optimal Degree of Commitment to an Intermediate Monetary Target. The Quarterly Journal of Economics 100: 1169-89. [CrossRef]

Rose, Andrew. 2000. One Money, One Market: The Effect of Common Currencies on Trade. Economic Policy 15: 7-45. [CrossRef]

Rose, A., and T. Stanley. 2005. A Meta-Analysis of the Effects of Common Currencies on International Trade. Journal of Economic Surveys 19: 347-65. [CrossRef]

Taylor, John. 1993. Discretion versus Policy Rules in Practice. Carnegie-Rochester Conference Series on Public Policy 39: 195-214. [CrossRef]

Viner, Jacob. 1950. The Customs Union Issue. New York: Carnegie Endowment for International Peace.

Weidman, Jens. 2021. Insolvency Figures will Rise Significantly. Augsburger Allgemeine, February 12.

Wyplosz, Charles. 2012. The ECB's Trillion Euro Bet. VoxEU. February 13. Available online: http://voxeu.org/index.php?q=node/7617 (accessed on 16 April 2021).

Zamani, Zahra, and Seyed Komail Tayebi. 2013. Synchronized Cycles during the Process of Economic Transition in Asia. Isfahan: University of Isfahan. 